\title{
Biomass and Lipid Productivity by Two Algal Strains of Chlorella sorokiniana Grown in Hydrolysate of Water Hyacinth
}

\author{
Swati Dahiya $\left.{ }^{1} \mathbb{(}\right)$, Raja Chowdhury ${ }^{1, *}$, Wendong Tao ${ }^{2} \mathbb{D}$ and Pradeep Kumar $^{3}$ \\ 1 Department of Civil Engineering, Indian Institute of Technology Roorkee, Uttakhand 247667, India; \\ swatidahiya100@gmail.com \\ 2 Department of Environmental Resources Engineering, SUNY College of Environmental Science and Forestry, \\ Syracuse, NY 13210, USA; wtao@esf.edu \\ 3 Department of Civil Engineering, SET, Sharda University, Greater Noida 201310, India; \\ indupradeep@gmail.com \\ * Correspondence: raja.chowdhury@ce.iitr.ac.in
}

Citation: Dahiya, S.; Chowdhury, R.; Tao, W.; Kumar, P. Biomass and Lipid Productivity by Two Algal Strains of Chlorella sorokiniana Grown in Hydrolysate of Water Hyacinth. Energies 2021, 14, 1411. https:// doi.org/10.3390/en14051411

Academic Editor: Byong-Hun Jeon

Received: 20 January 2021

Accepted: 20 February 2021

Published: 4 March 2021

Publisher's Note: MDPI stays neutra with regard to jurisdictional claims in published maps and institutional affiliations.

Copyright: (C) 2021 by the authors. Licensee MDPI, Basel, Switzerland This article is an open access article distributed under the terms and conditions of the Creative Commons Attribution (CC BY) license (https:// creativecommons.org/licenses/by/ $4.0 /)$

\begin{abstract}
Hydrolysate prepared from the chemical hydrolysis of water hyacinth biomass contains a high amount of solubilised carbohydrate and nutrients. This hydrolysate was utilised as a medium for the cultivation of two strains of Chlorella sorokiniana, isolated from a municipal wastewater treatment plant using two different media, i.e., BG-11 and Knop's medium. Different light intensities, light-dark cycles, and various concentrations of external carbon sources (monosaccharides and inorganic carbon) were used to optimise the microalgal growth. For the accumulation of lipids and carbohydrates, the microalgal strains were transferred to nutrient amended medium ( $\mathrm{N}$-amended and $\mathrm{P}$-amended). It was observed that the combined effect of glucose, inorganic carbon, and a 12:12 $\mathrm{h}$ light-dark cycle proved to be the optimum parameters for high biomass productivity ( $200 \mathrm{mg} / \mathrm{L} /$ day). For Chlorella sorokiniana 1 (isolated from BG-11 medium), the maximum carbohydrate content (22\%) was found in P-amended medium ( $\mathrm{N}=0 \mathrm{mg} / \mathrm{L}, \mathrm{P}: 3 \mathrm{mg} / \mathrm{L})$, whereas, high lipid content (17.3\%) was recorded in $\mathrm{N}$-amended medium $(\mathrm{N}=5 \mathrm{mg} / \mathrm{L}, \mathrm{P}=0 \mathrm{mg} / \mathrm{L}$ ). However, for Chlorella sorokiniana 2 (isolated from the Knop's medium), both lipid (17\%) and carbohydrate accumulation (12.3\%) were found to be maximum in the $\mathrm{N}$-amended medium. Chlorella sorokiniana 2 showed a high saturated lipid accumulation compared to other strains. Kinetic modelling of the lipid profile revealed that the production rate of fatty acids and their various constituents were species dependent under identical conditions.
\end{abstract}

Keywords: hydrolysate; Chlorella sorokiniana; biomass productivity; nutrient amended media; lipid; FAME (fatty acid methyl esters)

\section{Introduction}

Water hyacinth (Eichhornia crassipes), a floating aquatic plant that grows on wastewater, could help remove nutrients from it and prove to be a cheap and widely available biomass for developing various chemicals and fuels [1]. An efficient hydrolysis procedure could be developed to treat the water hyacinth biomass recovered from municipal wastewater. The resultant hydrolysate could later be used as a growth medium for microbial strains to produce value-added products [2]. Water hyacinth biomass is amenable to chemical treatment, and may not require costly enzymatic hydrolysis for enhanced sugar recovery. Various acids and electrochemical treatments were used for treating the water hyacinth biomass $[3,4]$. Treatment conditions, such as pressure, temperature, and concentration of hydrolysing agents affected sugar recovery, varying from 130-155 mg of sugar/g of treated biomass.

Hydrolysate prepared from biomass has been demonstrated to produce various valueadded chemicals, including fuels, using different microbial strains [5,6]. However, nutrient content also plays a vital role in the production of value-added products. Chowdhury and 
his co-workers [7-9] showed that nutrient recovery from biomass and its utilisation along with waste nutrients increased biofuel production considerably. The produced biofuel had reduced energy demands and GHG emissions. Hence, nutrient recovery from biomass should also be taken into account to evaluate the efficacy of a hydrolysis procedure.

Microalgae is one of the attractive routes for producing value-added products, by growing it on hydrolysate. Microalgae can accumulate various value-added products in the form of starch, protein, lipids, and various pigments that have high market value [10]. Types of value-added product depend on the algal species used, stress conditions applied, and various micronutrients present in the hydrolysate. In this study, an attempt was undertaken to study the formation of value-added products by algal strains isolated from a local oxidation pond used to treat municipal wastewater. Starch and lipids are stressinduced products, and during the production of such products growth of microalgae is reduced considerably. On the other hand, depending on the nitrogen $(\mathrm{N})$ or phosphorus $(\mathrm{P})$ limitation, the lipid profile also showed differences [11]. Saturated lipids provide better fuel quality compared to unsaturated lipids. Hence, it is desirable to have a high saturated lipid content in the cultured algae. Chu et al. [11] observed that nitrogen starvation enhanced unsaturated lipid concentration.

Hence, it was hypothesised that a two-step process in which a nutrient sufficient condition followed by either a nitrogen or phosphorus deficient condition would improve the lipid productivity and would change the lipid profile.

Therefore, in this study, an attempt was undertaken to study the formation of valueadded products by two algal strains isolated (using different growth media) from a local oxidation pond (used to treat municipal wastewater). A hydrolysate containing a high amount of solubilised carbohydrate and nutrients (prepared from the water hyacinth biomass using chemical reagent) was used as a growth medium for these two algae. Different light intensities, light-dark cycles, and concentrations of external sugar addition were used as the parameters to optimise the growth of algae. Effects of nutrient starvation, i.e., either $\mathrm{N}$ or P starvation, were estimated on lipid accumulation and fatty acid composition. Furthermore, a kinetic model was developed to understand the kinetics and rate-limiting steps in fatty acid elongation and unsaturation.

\section{Materials and Methods}

\subsection{Screening and Identification of Algal Strains}

For the isolation of algal species, a water sample was collected from a municipal wastewater stabilisation pond situated near Lakkarghat, Rishikesh, Uttarakhand, India. The sample was serially diluted for screening and isolating pure colonies of algal cells. Algal colonies were grown in two different media, i.e., modified BG-11 medium and Knop's medium, maintained at $\mathrm{pH}-9$ and a constant temperature $\left(25^{\circ} \mathrm{C}\right)$, and supplemented with an antibiotic and antifungal. (The compositions of both media are given in the Supplementary information, Tables S1 and S2). Genomic DNA of the isolated algal strains was extracted by using a MB561 HiPurA ${ }^{\mathrm{TM}}$ Marine Algal DNA Purification kit. The selected algal strain was identified using the $18 \mathrm{~S}$ ribosomal DNA (rDNA) sequence. The $18 \mathrm{~S}$ rDNA isolated algae (BG-11) was characterised, and procedural details are presented in Rani et al. [12]. A fragment of the $18 \mathrm{~S}$ rDNA region of the algal strain isolated from the Knop's medium was amplified by PCR (polymerase chain reaction: a method used to rapidly make several copies of a specific DNA sample). Forward and reverse DNA sequencing reaction of PCR amplicon was carried out using NS1- GTAGTCATATGCTTGTCTC and NS4- CTTCCGTCAATTCCTTTAAG primers [13]. Sequencing was done using a Sanger sequence chromatogram to generate reverse sequence data, forward sequence data, reverse complement, and $\mathrm{G}$ consensus data. The resulting data sequence was aligned using the NCBI (National Center for Biotechnology Information) GenBank and calculated with BLAST (basic local alignment search tool: this program compares nucleotide sequences to sequence databases and calculates the statistical significance) hits, with respect to the query sequence. The evolutionary history was inferred by using UGENE software [14]. 


\subsection{Biomass Growth}

A synthetic growth medium was prepared with similar constituents to the hydrolysate obtained by hydrolysing the water hyacinth biomass with $\mathrm{HNO}_{3}$ (Supplementary information, Table S3). Treatment conditions for hydrolysate preparation are given in Appendix A. The isolated microalgae species were grown in the synthetic hydrolysate medium under different conditions (such as different light intensity, different carbon sources and forms of monosaccharide, metal ions, etc.). The study was conducted in three different phases. A detailed pictorial representation of the experimental design is given in the Supporting Information (Figure S1).

In the first phase, the enhancement of microalgae growth was investigated by varying light intensity and medium supplementation. Each of these runs was carried out for 10 days under continuous illumination. Nitrate $(\mathrm{N})(75 \mathrm{mg} / \mathrm{L})$ and phosphate $(\mathrm{P})(15 \mathrm{mg} / \mathrm{L})$ were kept constant for all the studies, given in Table 1 . The growth pattern was checked every $24 \mathrm{~h}$ (Table 1$)$.

Table 1. Different parameters used in Phase 1. ( $24 \mathrm{~h}: 0 \mathrm{~h}$ light-dark cycle, nitrate: $\mathrm{N}=75 \mathrm{mg} / \mathrm{L}$, phosphate: $\mathrm{P}=15 \mathrm{mg} / \mathrm{L}, 140 \mathrm{rpm}$, initial biomass concentration: $400 \mathrm{mg} / \mathrm{L}$, temperature: $25^{\circ} \mathrm{C}$, Light source: fluorescent tube lights).

\begin{tabular}{|c|c|c|}
\hline S. No. & Medium Supplement (mg/L) & Light Intensity $\left(\mu \mathrm{mol} / \mathrm{s} / \mathrm{m}^{2}\right)$ \\
\hline 1. & Only Glucose (50) & 140 \\
\hline 2. & Only Glucose (100) & 140 \\
\hline 3. & Only Glucose (50) & 221 \\
\hline 4. & Inorganic-C source (75/day) + Glucose (50) & 221 \\
\hline 5. & Only Inorganic-C source (75/day) & 221 \\
\hline 6. & Inorganic-C (75/day) + Glucose (50) $+\mathrm{FeCl}_{3}(10)$ & 221 \\
\hline
\end{tabular}

In the second phase, different forms of monosaccharide were used to increase the algal biomass in a $12 \mathrm{~h}: 12 \mathrm{~h}$ light-dark cycle for 10 days. The growth pattern was monitored every $12 \mathrm{~h}$. Nitrate $(\mathrm{N})(75 \mathrm{mg} / \mathrm{L})$ and phosphate $(\mathrm{P})(15 \mathrm{mg} / \mathrm{L})$ concentrations were kept constant throughout the study. The light intensity was also kept constant at $221 \mu \mathrm{mol} / \mathrm{s} / \mathrm{m}^{2}$, which was found to be optimum in the first phase of the study. Details of the parameters used in this study are presented in Table 2. The experiments were carried out in photobioreactor in duplicate (Figure S2).

Table 2. Different medium supplements and their concentrations used in Phase 2. (12 h:12 h lightdark cycle, nitrate: $\mathrm{N}=75 \mathrm{mg} / \mathrm{L}$, phosphate: $\mathrm{P}=15 \mathrm{mg} / \mathrm{L}$, light intensity $=221 \mu \mathrm{mol} / \mathrm{s} / \mathrm{m}^{2}, 140 \mathrm{rpm}$, initial biomass concentration: $400 \mathrm{mg} / \mathrm{L}$, temperature: $25^{\circ} \mathrm{C}$, light source: fluorescent tube lights).

\begin{tabular}{cc}
\hline S. No. & Medium Supplement $(\mathbf{m g} / \mathrm{L})$ \\
\hline 1. & Only Glucose $(5 /$ day $)$ \\
2. & Only Xylose $(5 /$ day $)$ \\
3. & Glucose $(5 /$ day $)+$ Inorganic-C $(75 /$ day) \\
4. & Xylose $(5 /$ day) + Inorganic-C $(75 /$ day) \\
5. & Only Inorganic-C source $(75 /$ day $)$ \\
\hline
\end{tabular}

The third phase was divided into two parts; first part: nutrient sufficient media (composition was derived from the optimum parameters obtained from the above two studies) was used to enhance the algal growth. Algae were grown in a $12 \mathrm{~h}: 12 \mathrm{~h}$ light-dark phase for 6 days. The nutrient sufficient media contained glucose $(50 \mathrm{mg} / \mathrm{L})$, inorganic $\mathrm{C}(75 \mathrm{mg} / \mathrm{L} /$ day $)$, nitrate-N (60 mg/L), $\mathrm{NH}_{4}-\mathrm{N}$ (15 mg/L) and phosphate-P (15 mg/L). The second part emphasised the enhancement of the lipid accumulation by transferring the algal biomass under the nutrient amended conditions. Two different media were prepared: (i) $\mathrm{N}$-amended medium containing $5 \mathrm{mg} / \mathrm{L}$ of $\mathrm{NH}_{4}-\mathrm{N}$, glucose $(50 \mathrm{mg} / \mathrm{L})$, and 
inorganic C-source (125 mg/L); (ii) P-amended medium containing $3 \mathrm{mg} / \mathrm{L}$ of $\mathrm{PO}_{4}-\mathrm{P}$, glucose $(50 \mathrm{mg} / \mathrm{L})$, and inorganic C-source $(125 \mathrm{mg} / \mathrm{L})$.

\subsection{Analytical Methods}

\subsubsection{Determination of Biomass Growth}

To determine cell density, the optical density of algal cells was measured at $750 \mathrm{~nm}$ using a UV-VIS spectrophotometer (DR 6000, HACH). Algal biomass concentration was also measured as TSS (total suspended solids) using a standard gravimetric method [15].

\subsubsection{FAME Analysis}

Transesterification of lipids extracted from a culture grown in the hydrolysates was executed using a modified transesterification process. Lipids were transesterified in a mixture of solvents containing $0.5 \mathrm{~mL}$ methanol and $2.5 \mathrm{~mL} \mathrm{HCl}$. The solvent mixture and biomass were heated at $100{ }^{\circ} \mathrm{C}$ for $60 \mathrm{~min}$. After cooling it to room temperature, its fatty acid methyl esters (FAMEs) were retrieved using hexane. The hexane phase was then transferred to a glass vial for gas chromatography (Shimadzu GC-2014), equipped with a Restek Rtx-5 MS capillary column $(30 \mathrm{~m}, 0.25 \mathrm{~mm}, 0.25 \mu \mathrm{m})$ and a flame ionisation detector (FID). Other details of the analysis are given in Chowdhury et al. [9].

\subsection{Kinetic Modeling}

Two kinetic models were developed for the two strains used in this study. We needed to develop two kinetic models as one model may not fit well with another strain's data. The fatty acid precursor and compositions were also different for each of the strains.

Chlorella sorokiniana (Knop's media):

$$
\begin{gathered}
\frac{d P_{1}}{d t}=-K_{1} \\
\frac{d P_{2}}{d t}=K_{1}-K_{2} P_{2} \\
\frac{d P_{3}}{d t}=K_{2} P_{2}-K_{3} P_{3} \\
\frac{d P_{4}}{d t}=K_{3} P_{3}-\frac{K_{4}}{P_{4}} \\
\frac{d P_{5}}{d t}=\frac{K_{4}}{P_{4}}
\end{gathered}
$$

Chlorella sorokiniana (BG-11 media):

$$
\begin{gathered}
\frac{d P_{2}}{d t}=-K_{2} \\
\frac{d P_{3}}{d t}=-K_{3} P_{3}-K_{5} P_{3}+K_{2} \\
\frac{d P_{4}}{d t}=K_{3} P_{3}-K_{4} / P_{4} \\
\frac{d P_{5}}{d t}=\frac{K_{4}}{P_{4}} \\
\frac{d P_{6}}{d t}=K_{5} P_{3}
\end{gathered}
$$

where $P_{1}$ stands for C14:0, $P_{2}$ stands for C16:0, $P_{3}$ stands for C18:0, $P_{4}$ stands for C18:1, $P_{5}$ stands for C18:2, and $P_{6}$ stands for C20:0. Where $K_{1}$ to $K_{5}$ are the kinetic parameters.

In Knop's medium, $K_{1}:(\mathrm{mg} / \mathrm{mg}) /$ day, $K_{2}:$ per day, $K_{3}:$ per day, $K_{4}:(\mathrm{mg} / \mathrm{mg})^{2} /$ day. In BG-11 medium, $K_{2}:(\mathrm{mg} / \mathrm{mg}) /$ day, $K_{3}:$ per Day, $K_{4}:(\mathrm{mg} / \mathrm{mg})^{2} /$ day, $K_{5}:$ per day. 


\subsection{Quality Control/Quality Assurance}

All the experiments were carried out in duplicate. For quality assurance, a blank was incorporated whenever required. For statistical significance testing, one-way ANOVA followed by Tukey's test for multiple comparison was undertaken [16]. Significance level was tested either at $p=0.05$ or $p=0.01$ level.

\section{Results and Discussion}

\subsection{Identification and Characterisation of Microalgae}

As described in Section 2.1 for the BG-11 medium, the algal species were characterised as Chlorella Sorokinana (Figure S3), and the details about the strain and its identification procedures are given in Rani et al. [12]. For the algal strain grown in Knop's medium, the gel electrophoresis results showed a discrete PCR amplicon band of $1250 \mathrm{bp}$. The $18 \mathrm{~S}$ rDNA fragment was amplified using primers NS1 and NS4 (detail procedure are given in Section 2.1) and then sequenced. Phylogenetic trees of the strains were constructed using UGENE software [14]. Both the strains were found to be genetically similar to Chlorella Sorokinana (Figure S4). Therefore, in the present study, the microalgal strains were represented as Chlorella sorokiniana 1 for the algae isolated using BG-11 medium, and Chlorella sorokiniana 2 for the algae isolated using Knop's medium.

\subsection{Coupled Effect of Light Intensity and Carbon Source on Biomass Productivity of C. sorokiniana}

In this phase, microalgal growth was optimised using different parameters, as described in Section 2.2. Feng et al. [17] reported a decrease in biomass productivity at a high nitrate concentration. Nitrate in high concentrations may be toxic to microalgae species. Whereas, Blair et al. [18] observed no toxic effect of nitrate on the biomass productivity of Chlorella vulgaris. In the present study, nitrate was used as the sole source of nitrogen, and no such detrimental effect of nitrate on biomass productivity was observed. Six different combinations of the parameters used in this study are described in Table 1.

The biomass productivity of both the algal strains of $C$. sorokiniana was found to be dependent on the light intensity and carbon sources (Table $3 a, b)$.

Table 3. Change in cell density of (a) Chlorella sorokiniana 1 (isolated from BG-11 at pH-9); (b) Chlorella sorokiniana 2 (isolated from Knop's medium at pH-9), grown in synthetic hydrolysate under different light intensities and carbon sources.

\begin{tabular}{|c|c|c|c|}
\hline S. No. & Medium Supplement (mg/L) & Light Intensity $\left(\mu \mathrm{mol} / \mathrm{s} / \mathrm{m}^{2}\right)$ & $\begin{array}{c}\text { Biomass Productivity } \\
\text { (mg/L/Day) }\end{array}$ \\
\hline \multicolumn{4}{|c|}{ (a) } \\
\hline 1. & Only Glucose (50) & 140 & $31.49 \pm 0.03$ \\
\hline 2. & Only Glucose (100) & 140 & $39.81 \pm 0.03$ \\
\hline 3. & Only Glucose (50) & 221 & $56.77 \pm 0.02$ \\
\hline 4. & $\mathrm{NaHCO}_{3}(75 /$ day $)+$ Glucose $(50)$ & 221 & $153.46 \pm 0.04$ \\
\hline 5. & Only $\mathrm{NaHCO}_{3}(75 /$ day $)$ & 221 & $43.55 \pm 0.03$ \\
\hline 6. & $\mathrm{NaHCO}_{3}(75 /$ day $)+$ Glucose $(50)+\mathrm{FeCl}_{3}(10)$ & 221 & $24.13 \pm 0.01$ \\
\hline \multicolumn{4}{|c|}{ (b) } \\
\hline 1. & Only Glucose (50) & 140 & $106.26 \pm 0.01$ \\
\hline 2. & Only Glucose (100) & 140 & $160.31 \pm 0.03$ \\
\hline 3. & Only Glucose (50) & 221 & $163.57 \pm 0.01$ \\
\hline 4. & $\mathrm{Na}_{2} \mathrm{CO}_{3}(75 /$ day $)+$ Glucose $(50)$ & 221 & $170.14 \pm 0.01$ \\
\hline 5. & Only $\mathrm{Na}_{2} \mathrm{CO}_{3}(75 /$ day $)$ & 221 & $90.65 \pm 0.04$ \\
\hline 6. & $\mathrm{Na}_{2} \mathrm{CO}_{3}(75 /$ day $)+$ Glucose $(50)+\mathrm{FeCl}_{3}(10)$ & 221 & $74.72 \pm 0.01$ \\
\hline
\end{tabular}

For the algal strain isolated from the modified BG-11 medium (C. sorokiniana 1): High biomass productivity of $39.8 \mathrm{mg} / \mathrm{L} /$ day was found in the growth medium containing $100 \mathrm{mg} / \mathrm{L}$ of glucose (Table 3a). It was observed that low intensity light might affect the growth rate. Hence, for the subsequent studies, the light intensity was increased to $221 \mu \mathrm{mol} / \mathrm{s} / \mathrm{m}^{2}$ from $140 \mu \mathrm{mol} / \mathrm{s} / \mathrm{m}^{2}$. According to Sacristan de Alva et al. [19], adequate 
light intensity contributes to enhanced cell growth, as the light energy increases $\mathrm{CO}_{2}$ assimilation and enhances the cell dry weight.

Biomass productivity of $C$. sorokiniana 1 increased with the increase in light intensity, and the estimated biomass productivity was $56 \mathrm{mg} / \mathrm{L} /$ day in a $50 \mathrm{mg} / \mathrm{L}$ glucose dose. Optimum light stimulates the synthesis of critical components required for the cell division of Chlorella strains [20].

Supplementation of growth media with the inorganic carbon dose of $75 \mathrm{mg} / \mathrm{L} /$ day increased the biomass productivity further to $153 \mathrm{mg} / \mathrm{L} /$ day. The growth rate and lipid production could be controlled via regulating the availability of essential nutrients and trace elements [21,22]. Various ions, such as iron and magnesium, are essential for cellular mechanisms, including photosynthesis, cell division, respiration, intracellular transportation, and protein synthesis in microalgae $[23,24]$. However, in the present study, supplementation of metal ions (iron) with organic and inorganic carbon had a detrimental effect on biomass productivity, as it decreased to $24 \mathrm{mg} / \mathrm{L} /$ day from $153 \mathrm{mg} / \mathrm{L} /$ day (Table 3a). Wan et al. [25] reported that if the iron concentration in a medium is more than $55 \mathrm{mg} / \mathrm{L}$, it can reduce the biomass growth of Chlorella sp. However, in our study, we observed a toxic effect of iron at a much lower dose than the one reported by Wan et al. [25]. Besides iron, daily doses of inorganic carbon without the addition of organic carbon also reduced the biomass productivity to $43 \mathrm{mg} / \mathrm{L} /$ day from $153 \mathrm{mg} / \mathrm{L} /$ day (Table 3a). According to TSS measurements, the combined effects of the organic carbon and inorganic carbon in the presence of a high light intensity showed higher biomass productivity. Sun et al. [26] observed a positive effect of $\mathrm{NaHCO}_{3}$ on the biomass productivity of algae. However, the addition of $\mathrm{CO}_{2}$, along with $\mathrm{NaHCO}_{3}$ further improved biomass productivity. Hence, it is most likely that a supply of $\mathrm{CO}_{2}$ or organic carbon was the key behind the improved biomass productivity.

For the algal strain isolated from Knop's medium (C. sorokiniana 2): This strain showed higher biomass productivity compared to C. sorokiniana 1 . The highest biomass productivity of $160 \mathrm{mg} / \mathrm{L} /$ day was recorded in the growth medium containing $50 \mathrm{mg} / \mathrm{L}$ of glucose under a light intensity of $140 \mu \mathrm{mol} / \mathrm{s} / \mathrm{m}^{2}$. In the $100 \mathrm{mg} / \mathrm{L}$ of glucose dose, the biomass productivity decreased to $106 \mathrm{mg} / \mathrm{L} /$ day, from $160 \mathrm{mg} / \mathrm{L} /$ day (Table $3 \mathrm{~b}$ ).

Light intensity was increased from $140 \mu \mathrm{mol} / \mathrm{s} / \mathrm{m}^{2}$ to $221 \mu \mathrm{mol} / \mathrm{s} / \mathrm{m}^{2}$ to improve biomass productivity. With a $50 \mathrm{mg} / \mathrm{L}$ glucose dose, the estimated biomass productivity was $163 \mathrm{mg} / \mathrm{L} /$ day. An increase in light intensity could not improve biomass productivity further. However, the addition of an inorganic carbon source along with organic carbon (glucose) enhanced biomass productivity by $10 \mathrm{mg} / \mathrm{L}$ (biomass productivity: $170 \mathrm{mg} / \mathrm{L} /$ day). On the other hand, daily doses of only inorganic carbon $(75 \mathrm{mg} / \mathrm{L} /$ day $)$ in the growth media resulted in a biomass productivity of $90 \mathrm{mg} / \mathrm{L} /$ day (Table $3 \mathrm{~b}$ ). Hence, both carbon sources (inorganic and organic) are required for enhanced biomass productivity. This observation indicates that organic carbon helps the algal cells to reduce their dependency on light for inorganic carbon assimilation, and to channel the harvested light energy in the form of ATP (adenosine triphosphate) and NADPH (nicotinamide adenine dinucleotide phosphate) for cell growth [27]. Lin and $\mathrm{Wu}$ [28] reported that glucose enhanced the acetyl CoA/malonyl CoA for cell synthesis. These observations also suggest that Chlorella sp. utilises the energy from light in the non-glucose added mode, and uses the organic carbon source available for cell anabolism to obtain a remarkably higher growth rate [29]. As carbon uptake is the main mechanism for energy conversion and utilisation by microalgae, the consumption rate of carbon would be directly affected by nutrient supply, and further controls microalgal biomass production [30,31].

In addition to the carbon source, various trace elements also affect cell metabolism. Various ions, such as $\mathrm{Ca}^{2+}, \mathrm{Fe}^{3+}$, and $\mathrm{Cu}^{2+}$ are key factors involved in the physiological metabolism of algae, and increase the biomass yield and oil content at low concentration $[24,32]$. However, in the present study (Table 3b), the addition of ferric ion showed a detrimental effect on biomass productivity ( $74 \mathrm{mg} / \mathrm{L} /$ day of biomass production). 
The most common growth mode for microalgae is autotrophic cultivation using $\mathrm{CO}_{2}$ and light, while in the heterotrophic mode, algae only utilise organic compounds without light illumination [30,33]. However, according to the results observed in the present study, the combined effects of light intensity, and organic and inorganic carbon resulted in better algal biomass productivity for both the algal strains. Lin and $\mathrm{Wu}$ [28] also reported that the specific growth rate of $C$. vulgaris under mixotrophic growth conditions was significantly higher than the sum of those from photoautotrophic and heterotrophic growth, illustrating synergistic growth mechanisms. Mixotrophy comprises a dual system in which the autotrophic process utilises light energy and converts the light energy into chemical energy via photosynthesis. The heterotrophic process facilitates catabolism of organic compounds to obtain the energy essential for cell division $[29,31]$. On the other hand, carbon dioxide from cellular respiration becomes available for re-utilisation in photosynthesis under light conditions [30]. Therefore, the external $\mathrm{CO}_{2}$ supply is reduced.

A comparative study of biomass productivity was carried out to evaluate the attractiveness of the present strain's biomass productivity, compared to the other strains reported in the literature (Figure 1). The biomass productivity in this study was higher than the average biomass productivity of previous studies, which indicates that our study showed better results. If we evaluate only the biomass productivity of Chlorella sp., our study shows improved biomass production. It ultimately demonstrates that hydrolysate medium is an attractive growth medium for algal biomass production. One more advantage of using hydrolysate medium is that it is cheap compared to other growth media, and is produced from a waste source.

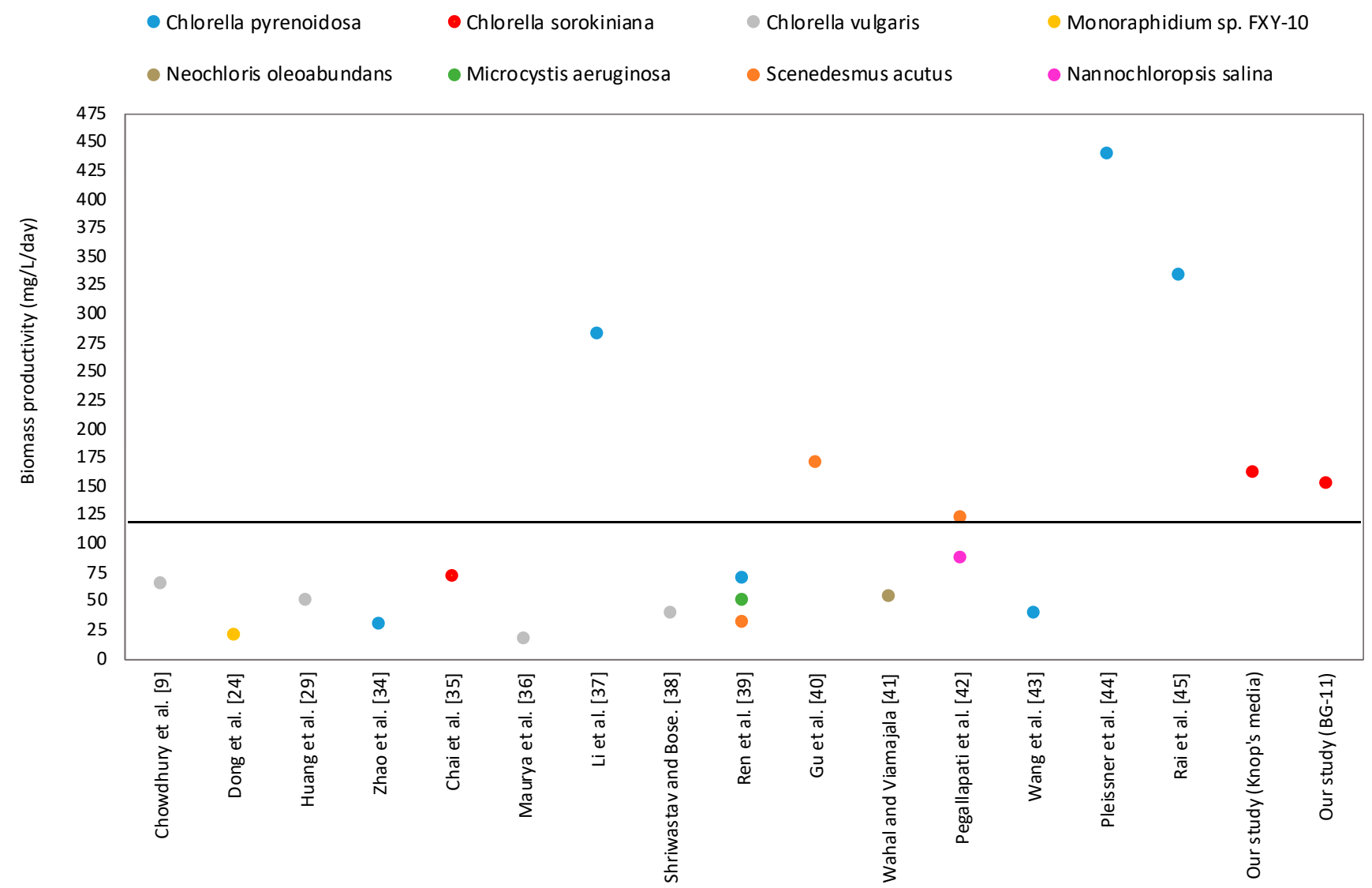

Figure 1. Comparison of biomass productivity of different algal species $[9,24,29,34-45]$ with the present study (dashed line represents the average value). 


\subsection{Effect of Monosaccharide Supplementation to the Hydrolysate Growth Medium on C. sorokiniana Biomass Productivity}

In the previous experiment, various doses of organic and inorganic carbon were added to understand their effects on biomass productivity. The hydrolysate prepared from waste biomass contains organic carbon in the form of $C 5$ and $C 6$ sugars. The hydrolysate also contains various forms of nitrogen, especially ammonium nitrogen. Hence, the effects of C5 sugars (xylose) and ammonium-N were evaluated based on biomass productivity of the two algal strains.

Ammonium is a growth substrate for many oleaginous microalgae [34]. Microalgae usually prefer ammonium over other nitrogen sources for intracellular metabolic activities [46]. In general, when nitrogen is supplied as nitrate, conversion of nitrate to ammonium consumes a considerable amount of energy compared to the uptake of ammonium [9]. Hence, uptake of nitrogen as nitrate is energy intensive and may reduce algal growth. Moreover, Rani et al. [12] observed higher uptake of ammonium-nitrogen by Chlorella sorokiniana1 compared to nitrate. So, in further study, the growth medium was supplemented with two different nitrogen sources, i.e., Nitrate-N (60 mg/L) and Ammonium-N (15 mg/L). Phosphate-P was kept at $15 \mathrm{mg} / \mathrm{L}$. A sufficient P supply ensures unhindered ATP production, which ultimately ensures algal growth [47-49].

Microalgae have a much higher growth potential when they use organic carbon for growth [50]. The use of exogenous carbon sources with either heterotrophic (without light) or mixotrophic (with light) culture modes has been reported to increase the biomass of several microalgal species [51-53]. The biomass growth rate and lipid content of Chlorella strains can be raised by supplementing the culture medium with organic carbon sources [35]. Various organic carbon sources, including polysaccharides, disaccharides, monosaccharides, starch, and ammonium acetate have been used for microalgal cultivation, but systematic comparisons of data between primary monosaccharides are limited. Hence, in this study, the effect of two different monosaccharides, i.e., glucose (C6 sugar) and xylose (C5 sugar) was analysed with respect to the optical density of media along with light/dark treatments to develop a cultivation mode that enhances biomass production. Monosaccharides and inorganic carbon sources were added every $24 \mathrm{~h}$ to the growth medium (with a concentration of $5 \mathrm{mg} / \mathrm{L} /$ day and $75 \mathrm{mg} / \mathrm{L} /$ day, respectively, details are given in Table 2). The light intensity was also kept constant at $221 \mu \mathrm{mol} / \mathrm{s} / \mathrm{m}^{2}$, which was optimum according to the first phase of the study, as explained in Section 3.2.

For C. sorokiniana 1: The highest biomass productivity $(38 \mathrm{mg} / \mathrm{L} /$ day) was observed in the growth medium supplemented with glucose along with an inorganic carbon source (Table 4a). Biomass productivity in the growth medium supplemented with xylose was found to be low (13 mg/L/day). In the absence of monosaccharides (control), the cultures displayed the typical green colour. Whereas, supplementation of xylose in the growth medium resulted in the discolouration of the culture, which could be due to the decline in the microalgal biomass. However, supplementation with glucose turned the microalgal culture to a deep green colour as compared to the control, which showed an increase in algal biomass and chlorophyll content (data not shown).

Some researchers, like Ribeiro et al. [54] and Derner et al. [55], have reported that the mixotrophic action of Chlorella sp. is possibly due to the photoperiod cycles, as the light availability is directly related to the inorganic carbon consumption. Similarly, in this study, the $12 \mathrm{~h}: 12 \mathrm{~h}$ light-dark cycle was responsible for the uptake of $\mathrm{NaHCO}_{3}$. In the mixotrophy, organic carbon such as glucose, provides auxiliary energy in the form of Acetyl-CoA, NADPH and other intermediates for the cellular biosynthesis [26,54]. 
Table 4. Change in cell density of (a) Chlorella sorokiniana 1 (isolated from BG-11 medium pH-9); (b) Chlorella sorokiniana 2 (isolated from Knop's medium pH-9), when grown in synthetic hydrolysate supplemented with different monosaccharides under $12 \mathrm{~h}: 12 \mathrm{~h}$ light-dark cycle (light intensity: $221 \mu \mathrm{mol} / \mathrm{s} / \mathrm{m}^{2}$ ).

\begin{tabular}{|c|c|c|}
\hline S. No. & Medium Supplement (mg/L) & Biomass Productivity (mg/L/Day) \\
\hline \multicolumn{3}{|c|}{ (a) } \\
\hline 1. & Glucose (5/day) $+\mathrm{NaHCO}_{3}(75 /$ day $)$ & $38.36 \pm 0.02$ \\
\hline 2. & Xylose $(5 /$ day $)+\mathrm{NaHCO}_{3}(75 /$ day $)$ & $13.42 \pm 0.05$ \\
\hline 3. & $\begin{array}{c}\text { Only } \mathrm{NaHCO}_{3}(75 / \text { day }) \\
\text { (b) }\end{array}$ & $27.13 \pm 0.01$ \\
\hline 1. & Only Glucose (10/day) & $160.28 \pm 0.04$ \\
\hline 2. & Only Xylose (10/day) & $92.15 \pm 0.09$ \\
\hline 3. & Glucose $(10 /$ day $)+\mathrm{Na}_{2} \mathrm{CO}_{3}(75 /$ day $)$ & $187.08 \pm 0.06$ \\
\hline 4. & Xylose $(10 /$ day $)+\mathrm{Na}_{2} \mathrm{CO}_{3}(75 /$ day $)$ & $134.61 \pm 0.03$ \\
\hline 5. & Only $\mathrm{Na}_{2} \mathrm{CO}_{3}$ (75/day) & $150.43 \pm 0.02$ \\
\hline 6. & Glucose (200) & $204.32 \pm 0.04$ \\
\hline
\end{tabular}

For C. sorokiniana 2: The highest biomass productivity $(187 \mathrm{mg} / \mathrm{L} /$ day $)$ was found in the growth medium supplemented with glucose $(10 \mathrm{mg} / \mathrm{L} /$ day) along with an inorganic carbon source (Table $4 \mathrm{~b}$ ), whereas in the growth medium supplemented with xylose, the biomass productivity was found to be less $(134 \mathrm{mg} / \mathrm{L} /$ day). Biomass productivity was estimated to be $150 \mathrm{mg} / \mathrm{L} /$ day when the growth media was supplemented with inorganic carbon $\left(\mathrm{Na}_{2} \mathrm{CO}_{3}\right)$ only. The biomass productivity under inorganic carbon supplement was higher than the one reported in the presence of xylose $+\mathrm{Na}_{2} \mathrm{CO}_{3}$, and lower than that observed under the glucose $+\mathrm{Na}_{2} \mathrm{CO}_{3}$ supplement. Hence, from the different mixtures of organic and inorganic carbon, it was observed that $C_{5}$ sugar reduced the growth of the algal strain, whereas C6 sugar increased the biomass productivity (Table 4b). Our results are corroborated by the findings of Chai et al. [35], who investigated the effect of glucose, galactose, fructose, and xylose on the growth of Chlorella sorokiniana UTEX 1230. They reported that supplementation with fructose promoted C. sorokiniana UTEX 1230 growth to a much lesser extent compared to glucose. Supplementation with galactose had no effect, and supplementation with xylose inhibited growth. Xylose supplementation had no effect on the growth of C. sorokiniana UTEX 1230 during the dark phase, whereas xylose significantly inhibited the algal growth under light conditions [35].

As compared to the strain isolated from the BG-11 medium (C. sorokiniana 1 ), algae isolated from Knop's medium (C. sorokiniana 2 ) showed improved biomass productivity. After observing such an encouraging result, a one-time glucose dose was also tried, to check its role in biomass productivity. An initial dose of $200 \mathrm{mg} / \mathrm{L}$ glucose increased the biomass productivity of the strain to $204 \mathrm{mg} / \mathrm{L}$. For a low glucose dose of $10 \mathrm{mg} / \mathrm{L} /$ day, the lower dry weight production suggested that a lower content of glucose might have been assimilated and converted into energy directly, leading to cell growth. A low glucose dose could not improve the production of the storage compounds that can increase biomass dry weight. Thus, both glucose and inorganic sources contributed to the algal growth, and likely had a cumulative effect. Whereas, xylose had a negative impact on algal growth.

Several researchers have evaluated the effect of monosaccharide supplementation on the biomass productivity of various strains of Chlorella sp. Woodworth et al. [56] found that the biomass productivity of $C$. vulgaris cultured under mixotrophic conditions (with glucose supplementation of $20 \mathrm{~g} / \mathrm{L}$ ) was higher compared to autotrophic and heterotrophic cultures. Similarly, Li et al. [57] investigated the impact of glucose on C. protothecoides, and applied a two-step process in which glucose was added in the first step and then removed in the second. Glucose addition in the process was found to influence biomass productivity and lipid accumulation, including the chlorophyll content, and protein and starch levels. Hawkins et al. [58] and Chai et al. [35] reported that $C$. sorokiniana utilised glucose as the primary monosaccharide compared to other sugars such as xylose, galactose, and fructose. Glucose, being the primary metabolic fuel, is more stable than other monosaccharides, and 
less susceptible to the formation of nonspecific glycol conjugates [35]. A perusal of the literature showed that the effect of glucose on biomass productivity of several Chlorella $\mathrm{sp}$. matched with our results obtained in the present investigation. Therefore, between $\mathrm{C} 5$ and C6 sugars, C6 sugar (Glucose) was found to be the better monosaccharide for the growth of both Chlorella sorokiniana 1 and Chlorella sorokiniana 2, in terms of biomass productivity.

\subsection{Effects of Different Parameters on C. sorokiniana Lipid Productivity and FAME Composition}

After optimising the different cultivation conditions, the microalgal biomass was grown in a $3 \mathrm{~L}$ photobioreactor using the best parameters for growth obtained from our previous study, i.e., the combination of glucose $(50 \mathrm{mg} / \mathrm{L})$ and inorganic C-source (75 mg/L) at $221 \mu \mathrm{mol} / \mathrm{s} / \mathrm{m}^{2}$ light intensity. As the $\mathrm{N}$ and $\mathrm{P}$ content was high in the growth medium, it is not possible to produce value-added products in the form of lipid and carbohydrate. However, increasing lipid accumulation by subjecting them to suboptimal conditions negatively affected lipid productivity due to the low growth [59]. Hence, in this study, after growth in a nutrient-sufficient condition (6 days), the algal biomass was transferred to a nutrient-amended medium for the value-added product formation (7 days). A similar strategy was also adopted previously by various researchers $[60,61]$. As described in Section 2.2, the nutrient-sufficient medium in this study consisted of glucose $(50 \mathrm{mg} / \mathrm{L})$, inorganic C-source (75 mg/L/day), nitrate-N (60 mg/L), $\mathrm{NH}_{4}-\mathrm{N}(15 \mathrm{mg} / \mathrm{L})$, and phosphate -P (15 mg/L). The study was conducted under $12 \mathrm{~h}: 12 \mathrm{~h}$ light-dark phase.

The biomass productivity in the photobioreactor under the nutrient sufficient condition was found to be $73 \mathrm{mg} / \mathrm{L} /$ day for C. sorokiniana 1 (Table 5), which was lower than the one obtained during our previous study (Table 3a). Nitrogen and phosphorus contents were measured on the 7th day, and the nitrate-N decreased to $0.082 \mathrm{mg} / \mathrm{L}$ from $60 \mathrm{mg} / \mathrm{L}$. Ammonium-N content was found to be 0.019 from the initial amount of $15 \mathrm{mg} / \mathrm{L}$, and phosphate-P content decreased to $0.837 \mathrm{mg} / \mathrm{L}$ from $15 \mathrm{mg} / \mathrm{L}$. For C. sorokiniana 2, biomass productivity was found to be $267 \mathrm{mg} / \mathrm{L} /$ day (Table 5). The nitrogen and phosphorus contents were measured on the 7 th day, and the nitrate- $\mathrm{N}$ decreased to $1.66 \mathrm{mg} / \mathrm{L}$ from $60 \mathrm{mg} / \mathrm{L}$. Ammonium-N content decreased to 0 from the initial amount of $15 \mathrm{mg} / \mathrm{L}$, and phosphate-P content decreased to $1.2 \mathrm{mg} / \mathrm{L}$ from $15 \mathrm{mg} / \mathrm{L}$.

Table 5. Change in cell density of C. sorokiniana isolated from BG-11 and Knop's media (pH-9) grown in synthetic hydrolysate growth medium with supplementation of $\mathrm{N}$ and $\mathrm{P}$ to accumulate a large amount of lipid.

\begin{tabular}{cccc}
\hline \multirow{2}{*}{ S. No. } & \multirow{2}{*}{ Growth Media } & \multicolumn{2}{c}{ Biomass Productivity (mg/L/day) } \\
\cline { 3 - 4 } & & C. sorokiniana 1 & C. sorokiniana 2 \\
\hline 1. & Nutrient Sufficient medium & $73.08 \pm 0.02$ & $267.11 \pm 0.03$ \\
2. & N-medium & $58.52 \pm 0.01$ & $94.37 \pm 0.02$ \\
3. & P-medium & $82.97 \pm 0.01$ & $178.12 \pm 0.03$ \\
\hline
\end{tabular}

The second part of this study emphasises the enhancement of lipid accumulation by transferring the algal biomass into the nutrient amended conditions. Two different media were prepared (details are given in Section 2.3.2). The first nutrient amended medium (referred to as $\mathrm{N}$ amended) contained an initial amount of $5 \mathrm{mg} / \mathrm{L}$ ammonium-N, with no phosphate-P in the medium. The other nutrient amended medium (referred to as $\mathrm{P}$ amended) had an initial amount of $3 \mathrm{mg} / \mathrm{L}$ phosphate-P, without a nitrogen source. The carbon sources were regularly added $\left(5 \mathrm{mg} / \mathrm{L}\right.$ of glucose and $125 \mathrm{mg} / \mathrm{L} \mathrm{NaHCO}_{3}$ ).

The biomass productivity was found to be higher in the P-amended medium for both the algal strains. C. sorokiniana 1 registered an $82.9 \mathrm{mg} / \mathrm{L} /$ day biomass productivity (Table 5), and C. sorokiniana 2 showed a biomass productivity of $178 \mathrm{mg} / \mathrm{L} /$ day (Table 5). Whereas, in the $\mathrm{N}$-amended medium, biomass productivity was found to be $58.5 \mathrm{mg} / \mathrm{L} /$ day (Table 5) and $94.3 \mathrm{mg} / \mathrm{L} /$ day, for C. sorokiniana 1 and C. sorokiniana 2 , respectively. Contrary 
to biomass productivity, the lipid accumulation was higher in the $\mathrm{N}$ - amended medium than the P-amended medium for both the algal strains (Tables 6 and 7).

Table 6. FAME composition of Chlorella sorokiniana 1 (isolated from BG-11 at pH-9) cultured in nutrient amended media. (3, 5, and 7 denote the culture time in days, and $\mathrm{N}$ and $\mathrm{P}$ represent the $\mathrm{N}$-amended medium and $\mathrm{P}$-amended media, respectively).

\begin{tabular}{|c|c|c|c|c|c|c|c|}
\hline $\begin{array}{c}\text { FAME } \\
\text { Component } \\
\mathbf{( \% )}\end{array}$ & 0-Day & $3-\mathrm{N}$ & 3-P & $5-\mathrm{N}$ & 5-P & $7-\mathrm{N}$ & 7-P \\
\hline C16:0 & $3.062 \pm 0.005$ & $4.822 \pm 0.004$ & $3.990 \pm 0.001$ & $6.738 \pm 0.008$ & $3.325 \pm 0.005$ & $2.682 \pm 0.001$ & $2.019 \pm 0.004$ \\
\hline C18:1 & $2.7 \pm 0.3$ & $2.9 \pm 0.1$ & $0.7 \pm 0.3$ & $2.5 \pm 0.1$ & $1.0 \pm 0.2$ & $2.9 \pm 0.2$ & $0.4 \pm 0.1$ \\
\hline C18:2 & $2.3 \pm 0.1$ & $1.2 \pm 0.2$ & $3.5 \pm 0.2$ & $5.0 \pm 0.2$ & $3.1 \pm 0.2$ & $3.3 \pm 0.3$ & $1.23 \pm 0.09$ \\
\hline C18:0 & $0.42 \pm 0.04$ & $2.2 \pm 0.2$ & $1.1 \pm 0.1$ & $2.11 \pm 0.04$ & $0.66 \pm 0.09$ & $0.31 \pm 0.04$ & $0.32 \pm 0.03$ \\
\hline C20:0 & 0 & $0.45 \pm 0.04$ & $0.59 \pm 0.03$ & $0.9 \pm 0.1$ & $0.183 \pm 0.006$ & $0.144 \pm 0.006$ & $1.0 \pm 0.2$ \\
\hline Total & $8.7 \pm 0.5$ & $11.6 \pm 0.5$ & $9.9 \pm 0.7$ & $17.2 \pm 0.4$ & $8.3 \pm 0.5$ & $9.3 \pm 0.6$ & $5.0 \pm 0.4$ \\
\hline
\end{tabular}

Table 7. Fatty acid methyl ester (FAME) composition of Chlorella sorokiniana 2 isolated from Knop's medium, pH-9 in nutrient-amended media. $(3,5$, and 7 denote the culture time in days, and $\mathrm{N}$ and $\mathrm{P}$ represent the $\mathrm{N}$-amended medium and P-amended medium, respectively).

\begin{tabular}{|c|c|c|c|c|c|c|c|}
\hline $\begin{array}{c}\text { FAME } \\
\text { Component } \\
\underset{(\%)}{(\%)}\end{array}$ & 0-Day & $3-N$ & 3-P & $5-\mathrm{N}$ & 5-P & $7-\mathrm{N}$ & 7-P \\
\hline C14:0 & $0.32 \pm 0.03$ & $1.1 \pm 0.8$ & $1.01 \pm 0.09$ & $0.54 \pm 0.05$ & $1.1 \pm 0.2$ & $0.6 \pm 0.2$ & $0.31 \pm 0.01$ \\
\hline C16:0 & $5.1 \pm 0.7$ & $7.8 \pm 0.7$ & $10 \pm 1$ & $7 \pm 1$ & $8 \pm 1$ & $7.6 \pm 0.7$ & $3.8 \pm 0.3$ \\
\hline C18:1 & $0.78 \pm 0.04$ & $0.057 \pm 0.008$ & 0 & $0.22 \pm 0.02$ & $0.16 \pm 0.01$ & $0.36 \pm 0.04$ & $0.13 \pm 0.02$ \\
\hline C18:2 & $2.3 \pm 0.2$ & $1.0 \pm 0.4$ & $1.1 \pm 0.3$ & $7 \pm 14$ & $1.66 \pm 0.09$ & $1.87 \pm 0.08$ & $1.27 \pm 0.02$ \\
\hline C18:0 & $2.3 \pm 0.4$ & $3.48 \pm 0.03$ & $3.4 \pm 0.4$ & $2.1 \pm 0.6$ & $2.9 \pm 0.5$ & $2.1 \pm 0.2$ & $1.43 \pm 0.08$ \\
\hline Total & $10 \pm 1$ & $13 \pm 1$ & $15 \pm 2$ & $17 \pm 3$ & $14 \pm 2$ & $12 \pm 1$ & $6.9 \pm 0.4$ \\
\hline
\end{tabular}

For C. sorokiniana 1: lipid accumulation increased to its highest (17.2\%) on the 5th day in the $\mathrm{N}$-amended medium. Whereas, in the P-amended medium, the highest $(9.9 \%)$ lipid production was observed on the 3rd day (Table 6).

Lipid productivity is one of the indicators for selecting an algal strain for biodiesel production. Hence, lipid productivity for both strains was estimated. It was observed that for C. sorokiniana 1, lipid productivity (taking into account biomass productivity in the nutrient sufficient condition) was 20 and $13 \mathrm{mg} / \mathrm{L} /$ day for the $\mathrm{N}$ - and P-amended media, respectively. On the other hand, C. sorokiniana 2, registered lipid productivity of 30 and $33 \mathrm{mg} / \mathrm{L} /$ day for the $\mathrm{N}$ - and P-amended media, respectively. Hence, although lipid production was low in the Knop's medium strain, because of high biomass productivity in the P-amended medium, this strain showed higher lipid productivity than the other strain.

Shi et al. [62] studied the marine algae Micractinium inermum, which could grow in phototrophic, mixotrophic, and heterotrophic conditions, and showed lipid productivity as high as $0.68 \mathrm{~g} / \mathrm{L} /$ day in the heterotrophic condition. Similarly, a Chlorella vulgaris strain studied by a research group at the University of Minnesota showed that the strain could grow in three modes, i.e., autotrophy, mixotrophy, and heterotrophy. The largest lipid productivity, however, was observed in the mixotrophic mode $(0.23 \mathrm{~g} / \mathrm{L} /$ day $)$, and the largest lipid content was observed when the culture was fed solely by glucose $(40 \%$ lipid content) [63]. In autotrophic and heterotrophic modes, the lipid content varied from 8-25\%. Similarly, Gladue and Maxey [64] observed that in the presence of acetate, Chlorella vulgaris could produce $0.027 \mathrm{~g} / \mathrm{L} /$ day lipid. Maurya et al. [36] used hydrolysate produced from algal biomass as a feed for producing algal biomass (Chlorella vulgaris). In the present study, supplementation of algal hydrolysate increased the lipid content in the algal cells (depending on the concentration of algal hydrolysate in the synthetic media), and lipid content varied from $23 \%$ to $32 \%$. However, lipid productivity $(0.007 \mathrm{~g} / \mathrm{L} /$ day) 
was very low compared to the other studies. To evaluate the attractiveness of the present strains, the lipid productivity of other species reported in the literature was collected, and is presented in Figure 2. An average productivity of $100 \mathrm{mg} / \mathrm{L} /$ day was estimated for the lipid productivity obtained from the literature. However, the high productivity was because of a few species of Scenedesmus and Micractinium. These species showed extremely high lipid productivity (500-2000 $\mathrm{mg} / \mathrm{L} /$ day) [65]. However, if one considered only the species of Chlorella, the average lipid productivity was $49 \mathrm{mg} / \mathrm{L} /$ day, whereas species of Nannochloropsis registered lipid productivity of $120 \mathrm{mg} / \mathrm{L} /$ day. Various species of Botryococcus showed average lipid productivity of $32 \mathrm{mg} / \mathrm{L} /$ day. Hence, the strains used in this study showed below-average lipid productivity compared to the average lipid productivity observed in the literature (Figure 2). However, most of the species showed lipid productivity ranging between $5-50 \mathrm{mg} / \mathrm{L} /$ day. Hence, to understand the attractiveness of the present strain as a biodiesel feedstock, a frequency distribution of the lipid productivity was plotted (data are not shown). The frequency distribution revealed that the most common lipid productivity obtained from the literature was between 20 to $40 \mathrm{mg} / \mathrm{L} /$ day. Hence, the analysis showed that the present strains showed a lipid productivity that is frequently encountered for most of the species, and these species showed a higher than average biomass productivity.

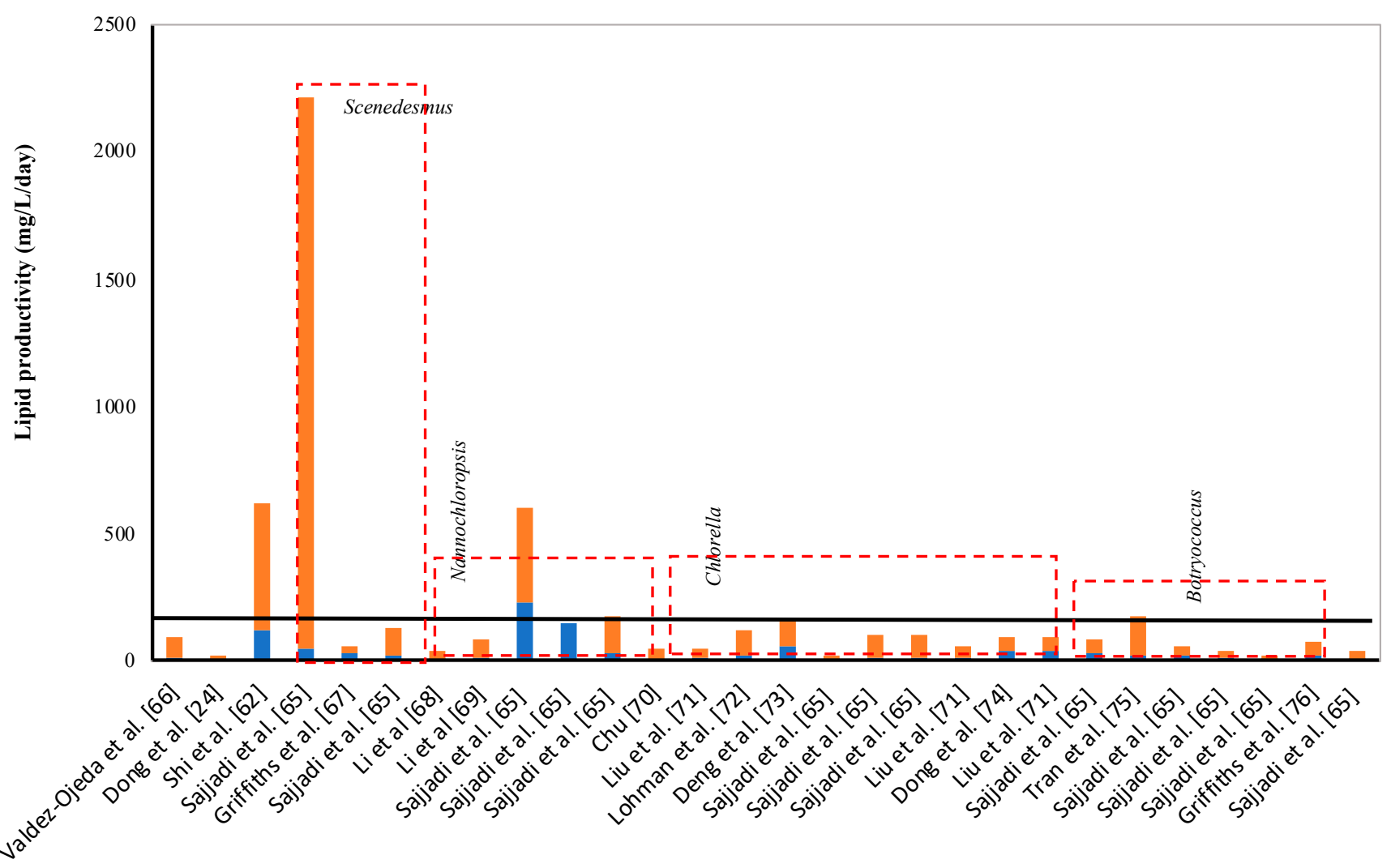

Figure 2. Lipid productivity of various species reported in the literature [24,62,65-76]. Two data bars (blue and orange) show the lowest and highest productivity of a particular species as given in that reference. The horizontal black line shows the average lipid productivity.

Beside lipid productivity and lipid content, lipid composition and individual fatty acid components also affect biodiesel quality. Hence, fatty acid profiles of individual strains were also evaluated in detail.

For C. sorokiniana 1 , in the $\mathrm{N}$-amended medium $(5-\mathrm{N})$, the highest saturated fatty acids (SFA) of $9.8 \%$, and total FAME content of $11.56 \%$ were reported on the 5th day. The total FAME content increased by $5 \%$ as compared to day 0 , amongst which polyunsaturated fatty acid (PUFA) increased by 3\% (Table S4, Supplementary Information). Lipid content started 
decreasing after 5 days, as only $9.3 \%$ and $5 \%$ of lipid production was estimated on the 7 th day in the N-amended medium (7-N) and P-amended medium (7-P), respectively (Figure 3). The SFA comprised C16:0 (Palmitic acid), C18:0 (Stearic acid), and C20:0 (Eicosanoic acid). In the present study, C16:0 constituted a significant fraction of SFA, whereas C18:1 and C18:2 were the major fractions of unsaturated fatty acid.

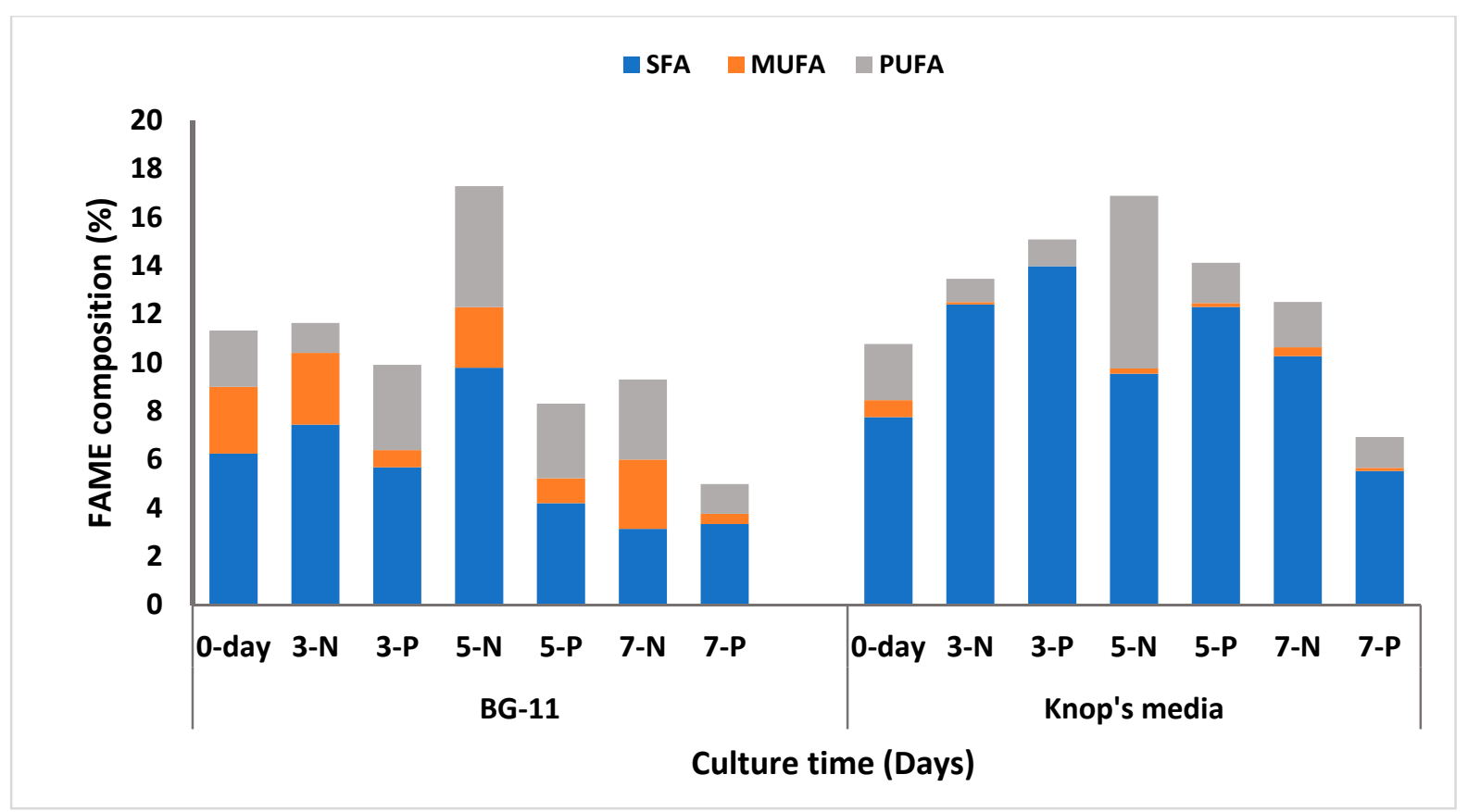

Figure 3. FAME composition of Chlorella sorokiniana isolated from BG-11 and Knop's media (at pH-9) cultured in nutrient amended media.

Contrary to lipid accumulation, the highest carbohydrate content was recorded in the $\mathrm{P}$-amended medium at the end of the study $(22 \%)$.

For C. sorokiniana 2: Lipid accumulation on the initial day (referred to as 0 day) was $10.87 \%$ (Figure 3) of which $72 \%$ represents the SFA. After that, the lipid accumulation increased in both the media. On the 3rd day, (referred to as 3-N and 3-P) accumulated lipid was $13.43 \%$ and $15.09 \%$ in the $\mathrm{N}$-amended medium and P-amended medium, respectively (Table 7). While, $92 \%$ of the total FAME composition consisted of SFA (Table S5, supplementary information). The highest lipid content was observed on the 5th day, with $16.88 \%$ and $14.07 \%$ in the $\mathrm{N}$-amended medium (referred as $5-\mathrm{N}$ ) and P-amended medium (referred as 5-P), respectively (Figure 3). In the N-amended medium (5th day), the content of PUFA was $42 \%$ of the total FAME composition, and was found to be the highest compared to the other days. SFA content was estimated to be $56 \%$ of the total FAME, and the rest was monounsaturated fatty acid (MUFA). However, in the P-amended medium, $88 \%$ of the total FAME was SFA, and the rest were MUFA and PUFA. Lipid content declined after 5 days as only $12.51 \%$ and $6.92 \%$ of lipid was estimated on 7 th day in the $\mathrm{N}$-amended medium (7-N) and P-amended medium (7-P), respectively (Table 7). In the $\mathrm{N}$-amended medium (5th day), the total FAME content was the highest compared to the other days, but the composition of SFA alone was less. Whereas in the P-amended media, the SFA alone comprised the maximum FAME composition, whereas MUFA and PUFA were only about $1-2 \%$. At the end of the study, the carbohydrate content was estimated to be higher in the $\mathrm{N}$-amended medium $(12.7 \%)$ than the P-amended medium (3.13\%). This result was found to be contrary to the algae isolated from the BG-11 medium.

According to the biodiesel standard EN 14214, IS 15607 and ASTM D-6751, the linolenic methyl ester (produced from C18:3 FA) content of biodiesel must be less than $12 \%$, and the polyunsaturated methyl ester (at least four double bonds) content must be less 
than $1 \%$ [77]. In the present study, for both the algal strains, the proportion of linolenic acid was 0 , which satisfied the standard of biodiesel. Compared to the present strains, Huang et al. [29] reported that marine algae Phaeodactylum tricornutum showed enhanced lipid productivity under nitrogen deprived conditions. Whereas, Isochrysis zhangjiangensis showed enhanced lipid productivity under phosphorus deficient conditions, which is in accordance with our observations. Fu et al. [78] observed that phosphorus supplementation enhanced the synthesis of saturated fatty acids, while curtailing the unsaturated fatty acid production pathways. Zhu et al. [79] and Singh et al. [80] also discussed in their work that all nitrogen limited conditions led to an increasing proportion of C18:1. Whereas, $\mathrm{Chu}$ et al. [11] observed that nitrogen deficiency increased unsaturated fatty acids, including mono and poly unsaturated fatty acids. Supplementing the media with P increased lipid production. Both $\mathrm{N}$ and $\mathrm{P}$ limitation affected the lipid productivity.

In the present study, it was observed that for the algal strain isolated from Knop's medium, i.e., C. sorokiniana 2, when grown in nutrient amended medium, especially P-amended medium, the major fraction of the saturated fatty acid was C16:0. At the same time, a minor fraction of C14:0 was also observed. However, for the other strain (BG-11), no C14:0 fatty acid was detected (Tables 6 and 7). C. sorokiniana 1 accumulated more unsaturated fatty acid in the $\mathrm{N}$-amended media than that in the P-amended media. Whereas, C. sorokiniana 2 accumulated almost $80 \%$ saturated fatty acids in both media. A considerable portion of $\mathrm{C} 18: 0$ was also detected in C. sorokiniana 2, making it more suitable for producing biodiesel compared to the other strain (BG-11).

From a review of this study, it was observed that the constituents of FAME were different in the two strains, and the most striking difference was found with respect to the saturated and unsaturated fatty acids. To better understand the inherent difference in fatty acid production, kinetic modeling of the fatty acid profile of these strains was carried out. Before presenting a kinetic model, one needs to know the various fatty acids which are being used to produce neutral lipids and free fatty acids. In this study, C14:0 (myristic acid) was the first fatty acid produced, which later elongated to C16:0 and C18:0. These saturated fatty acids were produced from shorter chain fatty acids by the delta elongase enzyme (Figure 4). The saturated fatty acids were later converted to unsaturated fatty acids, and delta desaturase enzyme was used to catalyse the conversion. However, depending on the position of the unsaturated bond, different desaturase enzymes act on a particular fatty acid. For simulating such a conversion, it was assumed that the kinetics were first order (Section 2.4). C. sorokiniana 1 produced C16:0, C18:0, C 20:0 as SFA, and C18:1 and C18:2 as the unsaturated fatty acid. Hence, C16:0 worked as the precursor for the production of other fatty acids, and the rate of production of C16:0 was assumed as zero-order kinetics. Other rate constants were modeled as first order (details of the model are provided in Section 2.4.). For C.sorokiniana 2, C14:0 appeared to act as a precursor for producing other higher-order chain fatty acids.

From a perusal of the kinetic coefficients obtained from the models, no definite trend was observed. Some of the kinetic coefficients were higher in C. sorokiniana 1, compared to C. sorokiniana 2. The maximum kinetic coefficient for C. sorokiniana 1 and C. sorokiniana 2 was for the conversion of $\mathrm{C} 16: 0$ to $\mathrm{C} 18: 0$, and $\mathrm{C} 18: 0$ to $\mathrm{C} 18: 1\left(\mathrm{~K}_{3}\right)$. Prima facie, it seems that the conversion was a bit higher in C. sorokiniana 1 compared to C. sorokiniana 2. Similarly, some of the kinetic coefficients were quite different in the $\mathrm{N}$-amended medium compared to the P-amended medium. Therefore, to understand the statistical difference among the kinetic coefficients, one-way ANOVA followed by Tukey's test for multiple comparison of means were undertaken [16]. From a perusal of the ANOVA, it was observed that the kinetic coefficients for $C$. sorokiniana 2 were statistically significant $(p=0.05)$. Later, Tukey's test [16] revealed that $\mathrm{K}_{3}$ was statistically significant compared to other kinetic coefficients (Table 8). However, no such difference was observed between kinetic coefficients obtained using the $\mathrm{N}$-amended and P-amended media. Similarly, no such statistical significance was observed between kinetic coefficients obtained for C. sorokiniana 1 and C. sorokiniana 2 . Hence, the statistical analysis revealed that the kinetics of lipid production for the strains 
are the same, even though there were some differences observed in lipid quantity and lipid profile between the two strains. It can also be deduced that the C18:0 production and conversion to $\mathrm{C} 18: 1$ were quite fast. Hence, the rate-limiting steps for lipid production were most likely the production of C14:0 and C16:0, and their conversion (for C. sorokiniana 2).

\section{Myristic acid (C14:0)}

\section{Elongase}

\section{Palmitic acid (C16:0)}

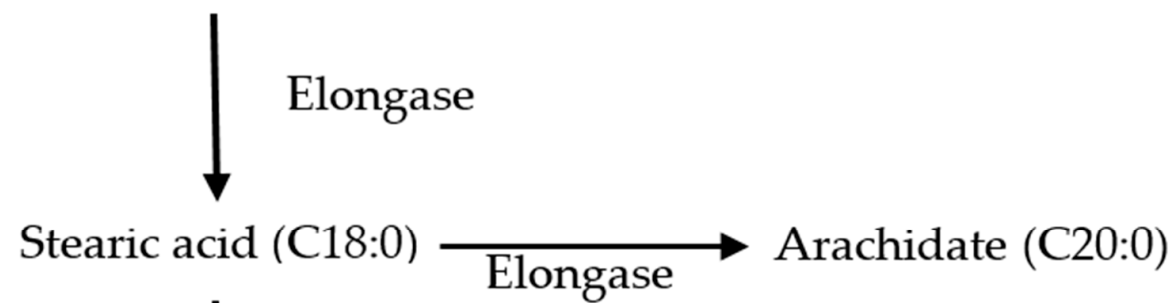

\section{$\Delta-9$ desaturase}

\section{Oleic acid (C18:1)}

\section{$\Delta-12$ desaturase}

\section{Linoleic acid (C18:2)}

Figure 4. Pathway involved in the present study for lipid formation.

Table 8. Kinetic coefficients of the interconversion of various fatty acids.

\begin{tabular}{ccccc}
\hline \multirow{2}{*}{$\begin{array}{c}\text { Kinetic Parameters } \\
\left(\mathbf{d}^{-1}\right)\end{array}$} & \multicolumn{2}{c}{ C. sorokiniana $\mathbf{2}$} & \multicolumn{2}{c}{ C. sorokiniana 1 } \\
\cline { 2 - 5 } K1 & N Amended & P Amended & N Amended & P Amended \\
K2 & $0.28 \pm 0.02^{* *}$ & $0.34 \pm 0.04^{* *}$ & NA & NA \\
K3 & $0.15 \pm 0.05$ & $0.27 \pm 0.02$ & $0.25 \pm 0.01 * *$ & $0.14 \pm 0.01 * *$ \\
K4 & $0.7 \pm 0.5$ & $0.5 \pm 0.1$ & $1.0 \pm 0.3$ & $0.9 \pm 0.2$ \\
K5 & $4 \times 10^{-5} \pm 1 \times 10^{-5 *}$ & $7 \times 10^{-6} \pm 2 \times 10^{-6 *}$ & $2.77 \times 10^{-4} \pm 5.06 \times 10^{-6 *}$ & $5.1 \times 10^{-5} \pm 0.4 \times 10^{-5 *}$ \\
& NA & NA & $0.19 \pm 0.05$ & $0.4 \pm 0.1$ \\
\hline
\end{tabular}

${ }^{*}\left(\mathrm{mg}-\mathrm{mg}^{-1}\right)^{2} /$ day $^{* *}\left(\mathrm{mg}-\mathrm{mg}^{-1}\right) /$ day.

To better understand the lipid production, the biochemical processes responsible for lipid production were also examined. Lipid production is a stress-induced phenomenon. Under nitrogen depleted conditions, adenosine monophosphate (AMP) can be decomposed into inosine monophosphate (IMP) and $\mathrm{NH}_{4}{ }^{+}$, and catalysed by AMP deaminase as a way to release ammonia. The decrease of AMP, a co-substrate for isocitrate dehydrogenase catalysing the transformation of isocitrate to $\alpha$-ketoglutarate, will disturb the Kreb's cy- 
cle [81] and, as a result, the mitochondrion accumulates isocitrate that remains imbalanced with citrate. Excess non-metabolised citrate is then transported to the cytoplasm via the citrate-malate shuttle to be converted into acetyl-CoA by ATP-citrate lyase (ACL), which is an additional pathway in oleaginous microorganisms. Under conditions of nitrogen exhaustion, the flow of carbon in oleaginous microorganisms is transferred towards the accumulation of citric acid, which is later transformed to acetyl-CoA, a precursor for fatty acid synthesis. The present study appears to support these observations, as nitrogen amended media seemed to trigger the lipid accumulation in both the strains.

When the availability of nitrogen is restricted, the synthesis of proteins and nucleic acids is curtailed. Carbon is used for protein, and nucleic acid synthesis used for lipid synthesis, and its concentration increases. Therefore, enhancing the activity of acetyl-CoA synthetase (ACS) and reducing the activity of isocitrate dehydrogenase (ICDH), resulted in more acetyl-CoA to participate in the lipid biosynthetic pathway, which was suggested to be beneficial for lipid accumulation [26]. Acetyl-CoA carboxylase (ACCase) converts acetyl-CoA into malonyl-CoA, the first, and rate-limiting, step of fatty acid biosynthesis [26]. Phosphoenolpyruvate can be converted into oxaloacetate by phosphoenolpyruvate carboxylase (PEPC), which decreases the flow of carbon towards lipid biosynthesis in microalgae. Accordingly, the inhibition of PEPC may be beneficial for lipid production.

In the P-amended medium, phosphorus was stored in the form of Poly-P, providing energy to participate in the synthesis of cellular materials, which enhanced cell growth and lipid accumulation, similar to ATP provided in the anabolic processes under nitrogen starvation $[11,79]$. According to the previous literature, the following potential mechanisms may be involved during the presence of phosphorus: (1) nitrogen limitation causes upregulation of malic enzyme, generating NADPH, which leads to lipid accumulation [37]; (2) upregulated glutamate dehydrogenase promotes the tricarboxylic acid cycle that offers intermediates and energy for lipid biosynthesis [46]; and (3) abundant phosphorus intake causes the downregulation of the ADP (Adenosine diphosphate)-glucose pyrophosphorylase activity of Chlorella sp., inhibiting starch synthesis, and regulating carbon assimilation towards the lipid synthesis pathway [79].

In the present study, nitrogen deficiency certainly inhibited the TCA (Tri-carboxylic acid) cycle [81] for energy production, and a part of the organic carbon participated in the lipid and starch production. It was observed that the presence of phosphorus promotes the fatty acid synthesis, and restricts the conversion of saturated fatty acids to unsaturated fatty acids.

\section{Conclusions}

The combined effects of glucose, inorganic carbon, and a $12 \mathrm{~h}: 12 \mathrm{~h}$ light-dark cycle were the optimum combination of parameters for high biomass productivity. N-deficiency enhanced the unsaturated lipid production in C. sorokiniana 1, whereas both $\mathrm{N}$ and $\mathrm{P}$ deficiency could not enhance the unsaturated lipid production in C. sorokiniana 2. Biodiesel produced from both the strains had a suitable quality, and which satisfied the biodiesel standards specified by various international regulating agencies. The biomass productivity of both the strains exceeded the average productivity of algal species reported in the previous literature. Hence, hydrolysate prepared from water hyacinth can be utilised as a cheap growth medium for growing different strains of Chlorella sorokiniana to accumulate a large amount of lipid.

Supplementary Materials: The following are available online at https:/ /www.mdpi.com/1996-107 3/14/5/1411/s1.

Author Contributions: Conceptualization, R.C.; Formal analysis, R.C.; Investigation, S.D.; Methodology, R.C.; Resources, W.T.; Writing—original draft preparation, S.D.; Writing—review \& editing, S.D., R.C. and W.T.; Visualization, R.C.; Supervision, R.C. and P.K.; Project administration, P.K.; Funding acquisition, R.C. and P.K. All authors have read and agreed to the published version of the manuscript. 
Funding: The research work is a collaborative study between the University of British Columbia, Canada (funding agency: IC-IMPACT) and Indian Institute of Technology, Roorkee, India, (Funding agency: Dept. of Biotechnology, Govt. of India; DBT-893-CED). Partial funding of this research was collected from a funding given by Dept. of Science and Technology (DST-1589-CED)

Institutional Review Board Statement: Not applicable.

Informed Consent Statement: Not applicable.

Data Availability Statement: Not applicable.

Acknowledgments: The authors are extremely thankful to Victor Lo and Asha Srinivasan (Dept. of Civil Engineering, University of British Columbia, Canada) for their support.

Conflicts of Interest: The authors declare no conflict of interest.

\begin{tabular}{|c|c|}
\hline PCR & Polymerase Chain Reaction \\
\hline NCBI & National Center for Biotechnology Information \\
\hline BLAST & Basic Local Alignment Search Tool \\
\hline ATP & Adenosine triphosphate \\
\hline NADPH & Nicotinamide adenine dinucleotide phosphate \\
\hline IMP & Inosine monophosphate \\
\hline ADP & Adenosine diphosphate \\
\hline TCA & Tri-carboxylic acid cycle \\
\hline ACS & Acetyl-CoA synthetase \\
\hline $\mathrm{ICDH}$ & Isocitrate dehydrogenase \\
\hline ACCase & Acetyl-CoA carboxylase \\
\hline AMP & Adenosine monophosphate \\
\hline ACL & ATP citrate lyase \\
\hline PUFA & Polyunsaturated Fatty acid \\
\hline MUFA & Mono-Unsaturated Fatty acid \\
\hline SFA & Saturated Fatty acid \\
\hline $\mathrm{CO}_{2}$ & Carbon dioxide \\
\hline $\mathrm{HNO}_{3}$ & Nitric acid \\
\hline $\mathrm{Na}_{2} \mathrm{CO}_{3}$ & Sodium carbonate \\
\hline $\mathrm{NaHCO}_{3}$ & Sodium bicarbonate \\
\hline $\mathrm{NO}_{3}$ & Nitrate \\
\hline $\mathrm{NH}_{4}$ & Ammonium \\
\hline $\mathrm{PO}_{4}$ & Phosphate \\
\hline PEPC & Phosphoenolpyruvate carboxylase \\
\hline FAME & Fatty acid methyl ester \\
\hline
\end{tabular}

\section{Appendix A}

Appendix A.1. Biomass Used

Naturally available water hyacinth biomass was collected from the stagnant water bodies present near the campus of the Indian Institute of Technology Roorkee, India. Biomass was washed several times with distilled water and dried in a hot air oven at $80{ }^{\circ} \mathrm{C}$ for $24 \mathrm{~h}$ before converting it into a powdered form.

\section{Appendix A.2. Hydrolysing Reagents}

Acetic acid $\left(\mathrm{CH}_{3} \mathrm{COOH}, 100 \%\right.$ purity, $\mathrm{ACS}$ grade), nitric acid $\left(\mathrm{HNO}_{3}, 70 \%\right.$ purity, reagent grade), ferric chloride anhydrous $\left(\mathrm{FeCl}_{3}, 98 \%\right.$ purity, powder) were used as the hydrolysing reagents. Sulphuric acid $\left(\mathrm{H}_{2} \mathrm{SO}_{4}, 98 \%\right.$ purity, reagent grade) was used as a reference hydrolysing reagent for the comparison. All the chemicals were purchased from Sigma Aldrich. 


\section{Appendix A.3. Hydrolysate Preparation}

The powdered forms of water hyacinth biomass were hydrolysed separately using $1 \%$, $2 \%$, and $5 \%$ concentrations of $\mathrm{CH}_{3} \mathrm{COOH}, \mathrm{HNO}_{3}$ and $\mathrm{FeCl}_{3}$ at $121^{\circ} \mathrm{C}$ and $103.4 \mathrm{kPa}(15 \mathrm{psi})$ for two time intervals, i.e., $30 \mathrm{~min}$ and $1 \mathrm{~h}$. The concentration of the reference hydrolysing reagent, $\mathrm{H}_{2} \mathrm{SO}_{4}$ was $1 \%$. The solid:liquid ratio was kept at 1:10 for all the experiments. All the hydrolysates prepared were neutralised and filtered before characterisation.

\section{Appendix A.4. Analytical Methods}

Appendix A.4.1. Characterisation of Water Hyacinth Biomass

The elemental composition of water hyacinth biomass was analysed before the hydrolysis of the biomass using a CHNS elemental analyser (Vario EL III, Elementar).

\section{Appendix A.4.2. Characterisation of the Hydrolysates}

Samples were first centrifuged at $4000 \mathrm{rpm}$ for $10 \mathrm{~min}$, and the supernatants were collected after passing through a $0.2 \mu \mathrm{m}$ syringe filter. The filtered supernatants were analyzed for nitrate (Nitrate-N) and orthophosphate using an ion chromatograph (Metrohm, 850 Professional IC), equipped with a Metrosep A Supp 5- 100/4.0 anionic column. Chemical oxygen demand (COD) was measured using the closed reflux method prescribed in Standard Methods [15]. The phenol sulphuric acid method (Dubois et al., 1956) was used to analyse the total carbohydrates present in the hydrolysates. Absorbance was measured by a UV-VIS spectrophotometer (DR 6000, HACH).

\section{Appendix A.4.3. Analysis of Reducing Sugars}

The estimation of simple sugars (glucose, xylose and arabinose) was carried out using high performance liquid chromatography (HPLC). The analysis was done by injecting filtered hydrolysate into HPLC (Agilent) equipped with an Aminex HPX-87H Column at $55^{\circ} \mathrm{C}$. $0.005 \mathrm{M} \mathrm{H}_{2} \mathrm{SO}_{4}$ was used as a mobile phase (flow rate: $0.6 \mathrm{~mL} / \mathrm{min}$ ), and a refractive index detector was used for detection.

\section{References}

1. Barua, V.B.; Kalamdhad, A.S. Effect of various types of thermal pretreatment techniques on the hydrolysis, compositional analysis and characterization of water hyacinth. Bioresour. Technol. 2017, 227, 147-154. [CrossRef]

2. Amezcua-Allieri, M.A.; Durán, T.S.; Aburto, J. Study of Chemical and Enzymatic Hydrolysis of Cellulosic Material to Obtain Fermentable Sugars. J. Chem. 2017, 2017, 1-9. [CrossRef]

3. Abdel-Fattah, A.F.; Abdel-Naby, M.A. Pretreatment and enzymatic saccharification of water hyacinth cellulose. Carbohydr. Polym. 2012, 87, 2109-2113. [CrossRef]

4. Harun, M.Y.; Radiah, A.B.D.; Abidin, Z.Z.; Yunus, R. Effect of physical pretreatment on dilute acid hydrolysis of water hya-cinth (Eichhornia crassipes). Bioresour. Technol. 2011, 102, 5193-5199.

5. Castro, Y.A.; Ellis, J.T.; Miller, C.D.; Sims, R.C. Optimisation of wastewater microalgae saccharification using dilute acid hydrolysis for acetone, butanol, and ethanol fermentation. Appl. Energy 2015, 140, 14-19. [CrossRef]

6. Moon, M.; Kim, C.W.; Farooq, W.; Suh, W.I.; Shrivastav, A.; Park, M.S.; Mishra, S.K.; Yang, J.W. Utilisation of lipid extracted algal biomass and sugar factory wastewater for algal growth and lipid enhancement of Ettlia sp. Bioresour. Technol. 2014, 163, 180-185. [CrossRef]

7. Chowdhury, R.; Freire, F. Bioenergy production from algae using dairy manure as a nutrient source: Life cycle energy and greenhouse gas emission analysis. Appl. Energy 2015, 154, 1112-1121. [CrossRef]

8. Chowdhury, R.; Franchetti, M. Life cycle energy demand from algal biofuel generated from nutrients present in the dairy waste. Sustain. Prod. Consum. 2017, 9, 22-27. [CrossRef]

9. Chowdhury, R.; Keen, P.L.; Tao, W. Fatty acid profile and energy efficiency of biodiesel production from an alkaliphilic al-gae grown in the photobioreactor. Bioresour. Technol. Rep. 2019, 6, 229-236. [CrossRef]

10. Brennan, L.; Owende, P. Biofuels from microalgae-A review of technologies for production, processing, and extractions of biofuels and co-products. Renew. Sustain. Energy Rev. 2009, 14, 557-577. [CrossRef]

11. Chu, F.-F.; Chu, P.-N.; Cai, P.-J.; Li, W.-W.; Lam, P.K.; Zeng, R.J. Phosphorus plays an important role in enhancing biodiesel productivity of Chlorella vulgaris under nitrogen deficiency. Bioresour. Technol. 2013, 134, 341-346. [CrossRef]

12. Rani, S.; Chowdhury, R.; Tao, W.; Srinivasan, A. Tertiary treatment of municipal wastewater using isolated algal strains: Treatment efficiency and value-added products recovery. Chem. Ecol. 2019, 36, 48-65. [CrossRef] 
13. Carney, L.T.; Reinsch, S.S.; Lane, P.D.; Solberg, O.D.; Jansen, L.S.; Williams, K.P.; Trent, J.D.; Lane, T.W. Microbiome analysis of a microalgal mass culture growing in municipal wastewater in a prototype OMEGA photobioreactor. Algal Res. 2014, 4, 52-61. [CrossRef]

14. Okonechnikov, K.; Golosova, O.; Fursov, M.; Ugene Team. Unipro UGENE: A unified bioinformatics toolkit Konstantin Okonechnikov. Bioinformatics 2012, 28, 1166-1167. [CrossRef] [PubMed]

15. Federation, Water Environmental, and American Public Health Association. Standard Methods for the Examination of Water and Wastewater; American Public Health Association (APHA): Washington, DC, USA, 2005.

16. Montgomery, D.C.; Elizabeth, A.P.; Vining, G.G. Introduction to Linear Regression Analysis; John Wiley \& Sons.: Hoboken, NJ, USA, 2012; p. 821.

17. Feng, D.; Chen, Z.; Xue, S.; Zhang, W. Increased lipid production of the marine oleaginous microalgae Isochrysis zhangjiangensis (Chrysophyta) by nitrogen supplement. Bioresour. Technol. 2011, 102, 6710-6716. [CrossRef]

18. Blair, M.F.; Kokabian, B.; Gude, V.G. Light and growth medium effect on Chlorella vulgaris biomass production. J. Environ. Chem. Eng. 2014, 2, 665-674. [CrossRef]

19. De Alva, M.S.; Pabello, V.M.L.; Ledesma, M.T.O.; Gómez, M.J.C. Carbon, nitrogen, and phosphorus removal, and lipid production by three saline microalgae grown in synthetic wastewater irradiated with different photon fluxes. Algal Res. 2018, 34, 97-103. [CrossRef]

20. Killam, A.; Myers, J. A special effect of light on the growth of Chlorella vulgaris. Am. J. Bot. 1956, 43, 569-572. [CrossRef]

21. Shin, Y.S.; Choi, H.I.; Choi, J.W.; Lee, J.S.; Sung, Y.J.; Sim, S.J. Multilateral approach on enhancing economic viability of lipid production from microalgae: A review. Bioresour. Technol. 2018, 258, 335-344. [CrossRef]

22. Liu, Z.-Y.; Wang, G.-C.; Zhou, B.-C. Effect of iron on growth and lipid accumulation in Chlorella vulgaris. Bioresour. Technol. 2008, 99, 4717-4722. [CrossRef]

23. Singh, P.; Kumari, S.; Guldhe, A.; Misra, R.; Rawat, I.; Bux, F. Trends and novel strategies for enhancing lipid accumulation and quality in microalgae. Renew. Sustain. Energy Rev. 2016, 55, 1-16. [CrossRef]

24. Dong, X.; Huang, L.; Li, T.; Xu, J.W.; Zhao, P.; Yu, X. The enhanced biomass and lipid accumulation in algae with an inte-grated treatment strategy by waste molasses and $\mathrm{Mg}^{2+}$ addition. Energy Sources Part A Recovery Util. Environ. Eff. 2020, 42, 1183-1192. [CrossRef]

25. Wan, M.; Jin, X.; Xia, J.; Rosenberg, J.N.; Yu, G.; Nie, Z.; Oyler, G.A.; Betenbaugh, M.J. The effect of iron on growth, lipid accumulation, and gene expression profile of the freshwater microalga Chlorella sorokiniana. Appl. Microbiol. Biotechnol. 2014, 98, 9473-9481. [CrossRef]

26. Sun, S.; Chen, W.; Tang, J.; Wang, B.; Cao, X.; Sun, S.; Sun, R.C. Synergetic effect of dilute acid and alkali treatments on frac-tional application of rice straw. Biotechnol. Biofuels 2016, 9, 217. [CrossRef]

27. Song, M.; Pei, H. The growth and lipid accumulation of Scenedesmus quadricauda during batch mixo-trophic/heterotrophic cultivation using xylose as a carbon source. Bioresour. Technol. 2018, 263, 525-531. [CrossRef]

28. Lin, T.S.; Wu, J.Y. Effect of carbon sources on growth and lipid accumulation of newly isolated microalgae cultured un-der mixotrophic condition. Bioresour. Technol. 2015, 184, 100-107. [CrossRef]

29. Huang, Y.; Luo, L.; Xu, K.; Wang, X.C. Characteristics of external carbon uptake by microalgae growth and associated effects on algal biomass composition. Bioresour. Technol. 2019, 292, 121887. [CrossRef]

30. Gao, F.; Yang, H.-L.; Li, C.; Peng, Y.-Y.; Lu, M.-M.; Jin, W.-H.; Bao, J.-J.; Guo, Y.-M. Effect of organic carbon to nitrogen ratio in wastewater on growth, nutrient uptake and lipid accumulation of a mixotrophic microalgae Chlorella sp. Bioresour. Technol. 2019, 282, 118-124. [CrossRef] [PubMed]

31. Li, X.; Li, W.; Zhai, J.; Wei, H. Effect of nitrogen limitation on biochemical composition and photosynthetic performance for fed-batch mixotrophic cultivation of microalga Spirulina platensis. Bioresour. Technol. 2018, 263, 555-561. [CrossRef] [PubMed]

32. Fazal, T.; Mushtaq, A.; Rehman, F.; Khan, A.U.; Rashid, N.; Farooq, W.; Rehman, M.S.U.; Xu, J. Bioremediation of textile wastewater and successive biodiesel production using microalgae. Renew. Sustain. Energy Rev. 2018, 82, 3107-3126. [CrossRef]

33. Safi, C.; Zebib, B.; Merah, O.; Pontalier, P.-Y.; Vaca-Garcia, C. Morphology, composition, production, processing and applications of Chlorella vulgaris: A review. Renew. Sustain. Energy Rev. 2014, 35, 265-278. [CrossRef]

34. Zhao, X.-C.; Tan, X.-B.; Yang, L.-B.; Liao, J.-Y.; Li, X.-Y. Cultivation of Chlorella pyrenoidosa in anaerobic wastewater: The coupled effects of ammonium, temperature and $\mathrm{pH}$ conditions on lipids compositions. Bioresour. Technol. 2019, 284, 90-97. [CrossRef] [PubMed]

35. Chai, S.; Shi, J.; Huang, T.; Guo, Y.; Wei, J.; Guo, M.; Li, L.; Dou, S.; Liu, L.; Liu, G. Characterisation of Chlorella sorokiniana growth properties in monosaccharide-supplemented batch culture. PLoS ONE 2018, 13, e0199873. [CrossRef] [PubMed]

36. Maurya, R.; Paliwal, C.; Chokshi, K.; Pancha, I.; Ghosh, T.; Satpati, G.G.; Pal, R.; Ghosh, A.; Mishra, S. Hydrolysate of lipid ex-tracted microalgal biomass residue: An algal growth promoter and enhancer. Bioresour. Technol. 2016, 207, 197-204. [CrossRef]

37. Li, Y.; Yuan, Z.; Mu, J.; Chen, D.; Feng, B. Proteomic analysis of lipid accumulation in Chlorella protothecoides cells by het-erotrophic N deprivation coupling cultivation. Energy Fuels 2013, 27, 4031-4040. [CrossRef]

38. Shriwastav, A.; Bose, P. Algal growth in photo-bioreactors: Impact of illumination strategy and nutrient availability. Ecol. Eng. 2015, 77, 202-215. [CrossRef]

39. Ren, L.; Wang, P.; Wang, C.; Chen, J.; Hou, J.; Qian, J. Algal growth and utilisation of phosphorus studied by combined mono-culture and co-culture experiments. Environ. Pollut. 2017, 220, 274-285. [CrossRef] 
40. Gu, H.; Nagle, N.; Pienkos, P.T.; Posewitz, M.C. Nitrogen recycling from fuel-extracted algal biomass: Residuals as the sole nitrogen source for culturing Scenedesmus acutus. Bioresour. Technol. 2015, 184, 153-160. [CrossRef]

41. Wahal, S.; Viamajala, S. Maximizing Algal Growth in Batch Reactors Using Sequential Change in Light Intensity. Appl. Biochem. Biotechnol. 2010, 161, 511-522. [CrossRef] [PubMed]

42. Pegallapati, A.K.; Nirmalakhandan, N. Internally illuminated photobioreactor for algal cultivation under carbon diox-idesupplementation: Performance evaluation. Renew. Energy 2013, 56, 129-135. [CrossRef]

43. Wang, H.; Xiong, H.; Hui, Z.; Zeng, X. Mixotrophic cultivation of Chlorella pyrenoidosa with diluted primary piggery wastewater to produce lipids. Bioresour. Technol. 2012, 104, 215-220. [CrossRef]

44. Pleissner, D.; Lau, K.Y.; Lin, C.S.K. Utilisation of food waste in continuous flow cultures of the heterotrophic microalga Chlorella pyrenoidosa for saturated and unsaturated fatty acids production. J. Clean. Prod. 2017, 142, 1417-1424. [CrossRef]

45. Rai, M.P.; Nigam, S.; Sharma, R. Response of growth and fatty acid compositions of Chlorella pyrenoidosa under mixotrophic cultivation with acetate and glycerol for bioenergy application. Biomass Bioenergy 2013, 58, 251-257. [CrossRef]

46. Liu, T.; Li, Y.; Liu, F.; Wang, C. The enhanced lipid accumulation in oleaginous microalga by the potential continuous nitro-genlimitation (CNL) strategy. Bioresour. Technol. 2016, 203, 150-159. [CrossRef] [PubMed]

47. Procházková, G.; Brányiková, I.; Zachleder, V.; Brányik, T. Effect of nutrient supply status on biomass composition of eukar-yotic green microalgae. J. Appl. Phycol. 2014, 26, 1359-1377. [CrossRef]

48. Beuckels, A.; Smolders, E.; Muylaert, K. Nitrogen availability influences phosphorus removal in microalgae-based wastewater treatment. Water Res. 2015, 77, 98-106. [CrossRef]

49. Aravantinou, A.F.; Manariotis, J.D. Effect of operating conditions on Chlorococcum sp. growth and lipid production. J. Environ. Chem. Eng. 2016, 4, 1217-1223. [CrossRef]

50. Li, Y.-R.; Tsai, W.-T.; Hsu, Y.-C.; Xie, M.-Z.; Chen, J.-J. Comparison of Autotrophic and Mixotrophic Cultivation of Green Microalgal for Biodiesel Production. Energy Procedia 2014, 52, 371-376. [CrossRef]

51. Lowrey, J.; Brooks, M.S.; McGinn, P.J. Heterotrophic and mixotrophic cultivation of microalgae for biodiesel production in agricultural wastewaters and associated challenges-A critical review. Environ. Boil. Fishes 2015, 27, 1485-1498. [CrossRef]

52. Zhan, J.; Rong, J.; Wang, Q. Mixotrophic cultivation, a preferable microalgae cultivation mode for biomass/bioenergy pro-duction, and bioremediation, advances and prospect. Int. J. Hydrogen Energy 2017, 42, 8505-8517. [CrossRef]

53. Paranjape, K.; Leite, G.B.; Hallenbeck, P.C. Strain variation in microalgal lipid production during mixotrophic growth with glycerol. Bioresour. Technol. 2016, 204, 80-88. [CrossRef]

54. Ribeiro, D.M.; Zanetti, G.T.; Julião, M.H.M.; Masetto, T.E.; Gelinski, J.M.L.; Fonseca, G.G. Effect of different culture media on growth of Chlorella sorokiniana and the influence of microalgal effluents on the germination of lettuce seeds. J. Appl. Biol. Biotechnol. 2019, 7, 006-010.

55. Derner, R.B.; Ohse, S.; Villela, M.; Carvalho, S.M.; Fett, R. Microalgae, products and applications. Ciência Rural 2006, 36, $1959-1967$. [CrossRef]

56. Woodworth, B.D.; Mead, R.L.; Nichols, C.N.; Kolling, D.R. Photosynthetic light reactions increase total lipid accumulation in carbon-supplemented batch cultures of Chlorella vulgaris. Bioresour. Technol. 2015, 179, 159-164. [CrossRef] [PubMed]

57. Li, Y.; Xu, H.; Han, F.; Mu, J.; Chen, D.; Feng, B.; Zeng, H. Regulation of lipid metabolism in the green microalga Chlorella protothecoides by heterotrophy-photoinduction cultivation regime. Bioresour. Technol. 2015, 192, 781-791. [CrossRef] [PubMed]

58. Hawkins, L.R. Utilisation of xylose for growth by the eukaryotic alga, Chlorella. Curr. Microbiol. 1999, 38, 360-363. [CrossRef]

59. Chen, B.; Wan, C.; Mehmood, M.A.; Chang, J.; Bai, F.; Zhao, X. Manipulating environmental stresses and stress toler-ance of microalgae for enhanced production of lipids and value-added products-A review. Bioresour. Technol. 2017, 244, 1198-1206. [CrossRef]

60. Roleda, M.Y.; Slocombe, S.P.; Leakey, R.J.; Day, J.G.; Bell, E.M.; Stanley, M.S. Effects of temperature and nutrient regimes on biomass and lipid production by six oleaginous microalgae in batch culture employing a two-phase cultivation strategy. Bioresour. Technol. 2013, 129, 439-449. [CrossRef] [PubMed]

61. Yoon, S.Y.; Hong, M.E.; Chang, W.S.; Sim, S.J. Enhanced biodiesel production in Neochloris oleoabundans by a semi-continuous process in two stage photobioreactors. Bioprocess. Biosyst. Eng. 2015, 38, 1415-1421. [CrossRef] [PubMed]

62. Shi, M.; Wei, H.; Chen, Q.; Wang, X.; Zhou, W.; Liu, J. Exploring an isolate of the oleaginous alga Micractinium inermum for lipid production: Molecular characterisation and physiochemical analysis under multiple growth conditions. J. Appl. Phycol. 2019, 31, 1035-1046. [CrossRef]

63. Heredia-Arroyo, T.; Wei, W.; Ruan, R.; Hu, B. Mixotrophic cultivation of Chlorella vulgaris and its potential application for the oil accumulation from non-sugar materials. Biomass Bioenergy 2011, 35, 2245-2253. [CrossRef]

64. Gladue, R.M.; Maxey, J.E. Microalgal feeds for aquaculture. Environ. Boil. Fishes 1994, 6, 131-141. [CrossRef]

65. Sajjadi, B.; Chen, W.-Y.; Raman, A.A.A.; Ibrahim, S. Microalgae lipid and biomass for biofuel production: A comprehensive review on lipid enhancement strategies and their effects on fatty acid composition. Renew. Sustain. Energy Rev. 2018, 97, 200-232. [CrossRef]

66. Valdez-Ojeda, R.A.; Serrano-Vázquez, M.G.D.R.; Toledano-Thompson, T.; Chavarría-Hernández, J.C.; Barahona-Pérez, L.F. Effect of Media Composition and Culture Time on the Lipid Profile of the Green Microalga Coelastrum sp. and Its Suitability for Biofuel Production. BioEnergy Res. 2021, 14, 241-253. [CrossRef] 
67. Griffiths, J.M.; Hille, R.P.V.; Harrison, S.T.L. Lipid productivity, settling potential and fatty acid profile of 11 microalgal species grown under nitrogen replete and limited conditions. J. Appl. Phycol. 2012, 24, 989-1001. [CrossRef]

68. Li, T.; Wang, W.; Yuan, C.; Zhang, Y.; Xu, J.; Zheng, H.; Xiang, W.; Li, A. Linking lipid accumulation and photosynthetic efficiency in Nannochloropsis sp. under nutrient limitation and replenishment. Environ. Boil. Fishes 2020, 32, 1619-1630. [CrossRef]

69. Li, Y.; Horsman, M.; Wang, B.; Wu, N.; Lan, C.Q. Effects of nitrogen sources on cell growth and lipid accumulation of green alga Neochloris oleoabundans. Appl. Microbiol. Biotechnol. 2008, 81, 629-636. [CrossRef]

70. Chu, W.L. Strategies to enhance production of microalgal biomass and lipids for biofuel feedstock. Eur. J. Phycol. 2017, 52, 419-437. [CrossRef]

71. Liu, A.-Y.; Chen, W.; Zheng, L.-L.; Song, L.-R. Identification of high-lipid producers for biodiesel production from forty-three green algal isolates in China. Prog. Nat. Sci. 2011, 21, 269-276. [CrossRef]

72. Lohman, E.J.; Gardner, R.D.; Pedersen, T.; Peyton, B.M.; Cooksey, K.E.; Gerlach, R. Optimised inorganic carbon regime for enhanced growth and lipid accumulation in Chlorella vulgaris. Biotechnol. Biofuels 2015, 8, 82. [CrossRef]

73. Deng, X.; Chen, B.; Xue, C.; Li, D.; Hu, X.; Gao, K. Biomass production and biochemical profiles of a freshwater microalga Chlorella kessleri in mixotrophic culture: Effects of light intensity and photoperiodicity. Bioresour. Technol. 2019, 273, 358-367. [CrossRef]

74. Dong, L.; Li, D.; Li, C. Characteristics of lipid biosynthesis of Chlorella pyrenoidosa under stress conditions. Bioprocess. Biosyst. Eng. 2020, 43, 877-884. [CrossRef]

75. Tran, H.L.; Kwon, J.S.; Kim, Z.H.; Oh, Y.; Lee, C.G. Statistical optimisation of cluture media for growth and lipid production of Botryococcus braunii LB 572. Biotechnol. Bioprocess. Eng. 2010, 15, 277-284. [CrossRef]

76. Griffiths, M.J.; Harrison, S.T.L. Lipid productivity as a key characteristic for choosing algal species for biodiesel production. Environ. Boil. Fishes 2009, 21, 493-507. [CrossRef]

77. Stephenson, P.G.; Moore, C.M.; Terry, M.J.; Zubkov, M.V.; Bibby, T.S. Improving photosynthesis for algal biofuels: Toward a green revolution. Trends Biotechnol. 2011, 29, 615-623. [CrossRef]

78. Fu, L.; Cui, X.; Li, Y.; Xu, L.; Zhang, C.; Xiong, R.; Zhou, D.; Crittenden, J.C. Excessive phosphorus enhances Chlorella reg-ularis lipid production under nitrogen starvation stress during glucose heterotrophic cultivation. Chem. Eng. J. 2017, 330, 566-572. [CrossRef]

79. Zhu, S.; Wang, Y.; Xu, J.; Shang, C.; Wang, Z.; Xu, J.; Yuan, Z. Luxury uptake of phosphorus changes the accumulation of starch and lipid in Chlorella sp. under nitrogen depletion. Bioresour. Technol. 2015, 198, 165-171. [CrossRef]

80. Singh, P.; Guldhe, A.; Kumari, S.; Rawat, I.; Bux, F. Investigation of combined effect of nitrogen, phosphorus and iron on lipid productivity of microalgae Ankistrodesmus falcatus KJ671624 using response surface methodology. Biochem. Eng. J. 2015, 94, 22-29. [CrossRef]

81. Bodner, G.M. The Tricarboxylic Acid (TCA), Citric Acid or Krebs Cycle. J. Chem. Educ. 1986, 63, 673-677. [CrossRef] 